DOE/ID/13551

Sustaining the Productivity and Function of Intensively Managed Forests

Final Report - 08/01/1997 - 08/31/2000

\author{
J. A. Burger \\ Y. Xu
}

March 2001

Work Performed Under Contract No. DE-FC07-97ID13551

For

U.S. Department of Energy

Assistant Secretary for

Environmental Management

Washington, DC

By

Virginia Polytechnic Institute and State University

Blacksburg, VA 
DOE/ID/13551

\title{
SUSTAINING THE PRODUCTIVITY AND FUNCTION OF INTENSIVELY MANAGED FORESTS
}

\section{FINAL REPORT}

08/01/1997 - 08/31/2000

\author{
James A. Burger \\ Yi-Jun $\mathrm{Xu}$
}

March 2001

Work Performed Under Contract No. DE-FC07-97ID13551

Prepared for the

U.S. Department of Energy

Assistant Secretary for

Environmental Management

Washington, DC

Prepared by

Virginia Polytechnic Institute and State University

Blacksburg, VA 


\section{Sustaining the Productivity and Function of Intensively Managed Forests}

\section{Final Project Report}

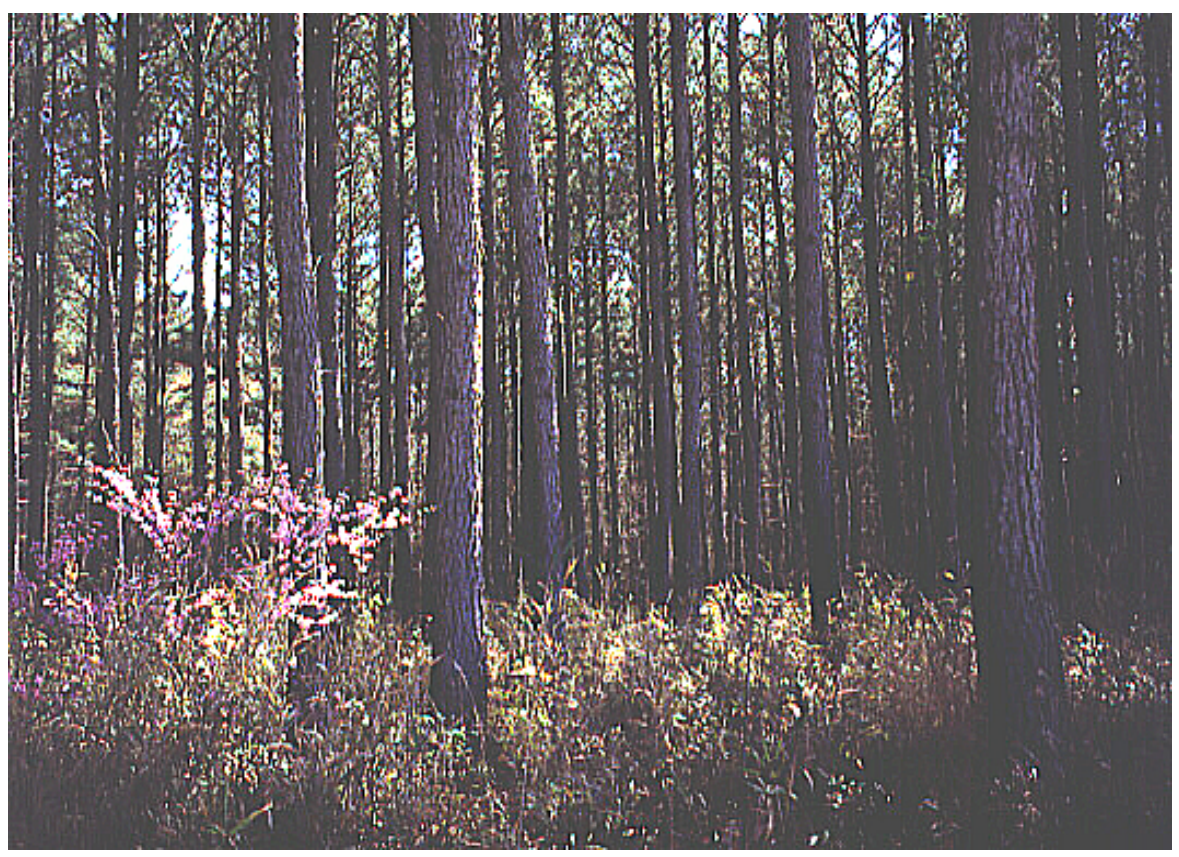

http://soils.fw.vt.edu/westvaco/

This document was compiled by

James A. Burger and Yi-Jun Xu Department of Forestry

Virginia Polytechnic Institute and State University

Blacksburg, Virginia 24061

March 23, 2001 
Period Covered: August 1997 to August 2000

Date of Report: $\quad$ March 23, 2001

Contractor: Virginia Polytechnic Institute and State University

Award:

DE-FC07-97ID13551

Investigators: James A. Burger, W. Michael Aust, and Yi-Jun Xu

Address: $\quad$ Department of Forestry, 228 Cheatham Hall

Virginia Polytechnic Institute and State University

Blacksburg, Virginia 24061

Phone: $\quad$ (540) 231-7680, (540) 231-4523, (540) 231-7250

Email:_ jaburger@vt.edu, maust@vt.edu, yjxu@vt.edu

Collaborators: Westvaco Corporation:

Steve Patterson and Denis P. Joliat

USDA Forest Service:

Carl C. Trettin

Emily A. Carter

\section{Project Summary:}

Researchers from Virginia Tech, Westvaco Corporation, and the USDA Forest Service have been cooperating on a study of sustainable forest management of wetland pine plantation systems. The study was initiated in 1991 and conducted in three 20-ha, Palustrine wetlands on the Lower Coastal Plain in South Carolina. Cause and effect relationships among intensive forest management practices, soil productivity, wetland functions, and carbon sequestration are being sought at the process level. The results will be used to develop guidelines and management models to minimize forest practice impacts on degradation of soils and site drainage, and optimize forest productivity, carbon sequestration, and wetland attributes. The main goal of this study is to ensure sustainable management of wetland forests in the southeastern United States.

The study is projected to measure soil, hydrology, and forest responses to several management scenarios across a complete forest cycle. From August 1997 to August 2000 the study has received funding as one of the Agenda 2020 projects, from the U.S. Department of Energy (Cooperative Agreement Number DE-FC07-97ID13551), the National Council of the Paper Industry for Air and Stream Improvement, and Westvaco Corporation. Quarterly progress reports were submitted regularly to the Department and all project participants. This final report is a summary of project results and progress that has been achieved during this 3 -year period. 


\section{TABLE OF CONTENTS}

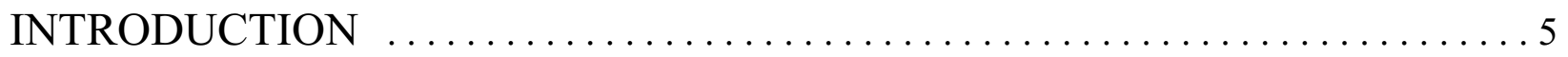

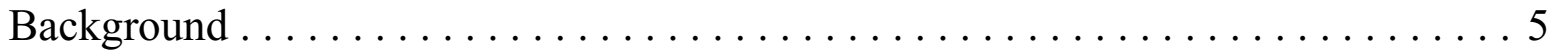

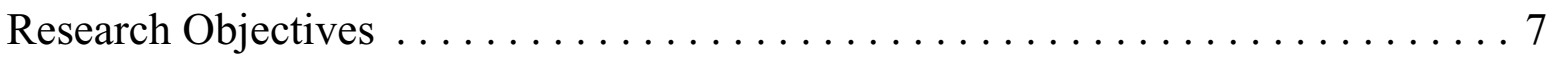

Long-Term Project Benefits $\ldots \ldots \ldots \ldots \ldots \ldots \ldots \ldots \ldots \ldots$

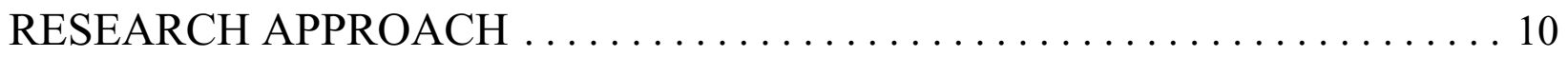

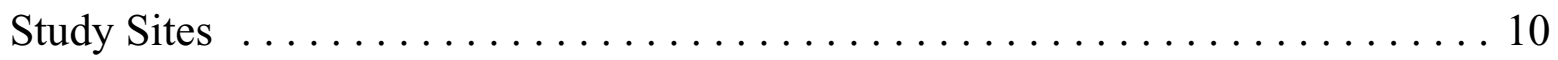

Treatment Design ................................ 10

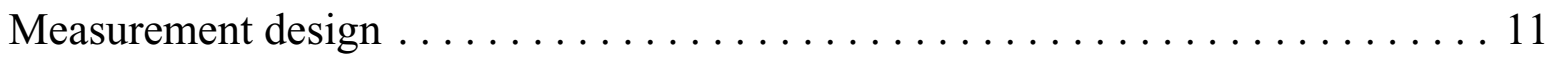

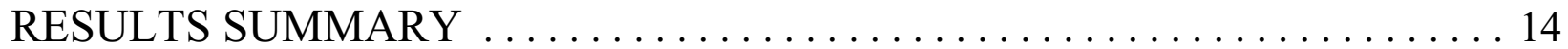

Site Conditions and Mensurational Characteristics $\ldots \ldots \ldots \ldots \ldots \ldots \ldots$

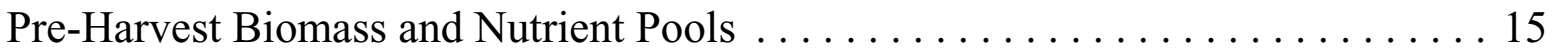

Trafficability and Soil Disturbance $\ldots \ldots \ldots \ldots \ldots \ldots \ldots \ldots \ldots \ldots \ldots \ldots \ldots \ldots$

Hydrologic Response to Harvesting . . . . . . . . . . . . . . . . 18

Hydrologic Response to Site Preparation . . . . . . . . . . . . . . . . . . 19

Early Pine Growth Responses to Soil Disturbance and Site Preparation . . . . . . . 20

Soil Quality Index Model . . . . . . . . . . . . . . . . . . . . . 21

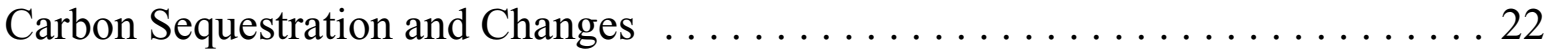

Vegetation Dynamics and Wetland Criteria $\ldots \ldots \ldots \ldots \ldots \ldots \ldots \ldots \ldots$

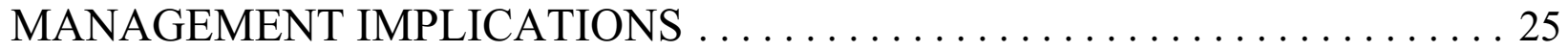

Wood Production, Carbon Sequestration and Conservation $\ldots \ldots \ldots \ldots . \ldots 25$

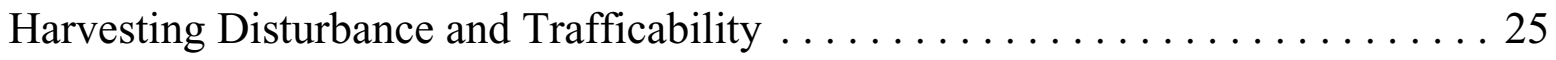


Hydrologic Responses to Harvesting and Site Preparation . . . . . . . . . . . 25

Soil Quality and Productivity Responses to Harvesting and Site Preparation . . . . 26

Vegetation Responses and the Role of Vegetation in Soil Recovery ......... 26

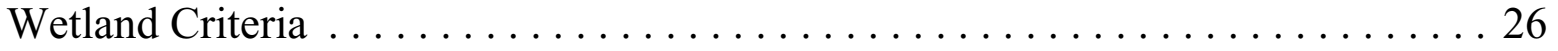

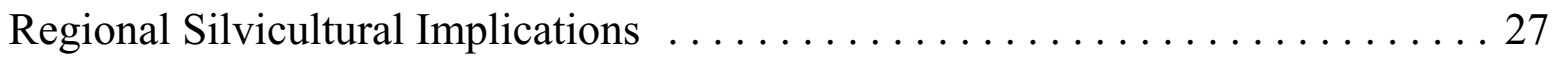

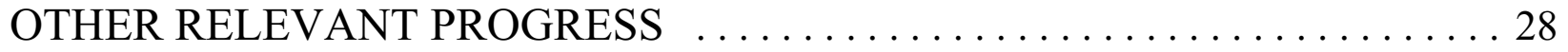

PROJECT-RELATED PUBLICATIONS $\ldots \ldots \ldots \ldots \ldots \ldots \ldots \ldots \ldots \ldots \ldots$

Research Articles .................................. 29

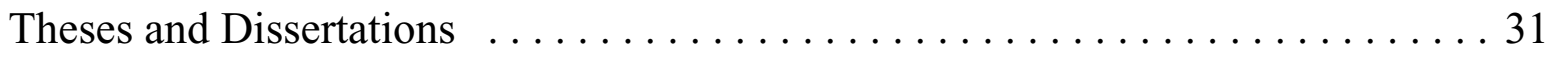

Presentation Abstracts . ................................... 31

Project Progress Reports . . . . . . . . . . . . . . . . . . . . . . . . . 34

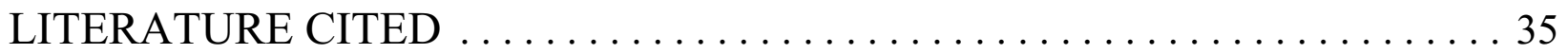




\section{INTRODUCTION}

\section{Background}

Intensive silviculture has been used to establish large-scale pine plantations on the southeastern coastal plain. At this time, approximately $16 \%$ of the total timberland in this region grows in wetland areas (Shepard et al., 1998), which amounts to over one million hectares (Aust et al., 1993). These wetland pine plantations are known to be among the most productive forests in the U.S. (Allen and Campbell, 1988) and have become a significant resource for fiber and wood production in the nation, a magnificent component of the region's landscape, and a unique system for coastal ecological processes, all of which provide numerous benefits to our society. Thus, maintaining forest productivity and ecological functions and values of these wetland forests is a common goal shared by forest industry, government agencies, environmental groups and the general public.

On the other hand, intensive silvicultural practices such as timber harvest using heavy machinery and site preparation have caused concerns about surface soil damage and hydrologic deterioration in forested wetlands. Impacts of vehicle trafficking on surface soils have long been investigated. The evolving state of our knowledge is reflected by numerous publications, e.g., early publications about fundamental mechanisms of vehicle trafficking on soil surfaces: Kögler (1933), Fröhlich (1934), Bodman and Robin (1948), Söhne (1951, 1952, 1953, and 1958); and books and review papers published in the past few decades: Barnes et al. (1971), Chancellor (1976), Froehlich et al. (1980), Greacen and Sands (1980), Soane et al. (1981a, 1981b, and 1982), Koolen and Kuipers (1983), Soane and van Ouwerkerk (1994), Stone (1984), Taylor (1992), Worrell and Hampson (1997). It is widely acknowledged that vehicle trafficking during timber harvesting can compress surface soil, increase bulk density, and decrease macroporosity and saturated hydraulic conductivity. As a result, water-related soil properties are adversely altered. These negative effects have been confirmed by some studies on skid trail impacts on forest wetland soils (e.g., Gent et al., 1983; Aust et al., 1993 and 1998). However, while changes in soil physical and hydraulic properties caused by timber harvesting are attributed to complicating site drainage, no report existed documenting the combined effects on actual dynamics of site hydrology and hydrologic recovery from harvest through stand establishment in forested wetlands.

Surface water table is the dominant factor determining an array of soil chemical, physical and biological processes. Periodic waterlogging results in soil oxidation / reduction (redox) conditions, which can have profound effects on the soil fertility. Redox has been identified as a master variable exerting strong influence on major soil chemical and biological processes (Bohn et al., 1985; McBride, 1994); adsorption-desorption and ion-exchange (McKee, 1970); mineral precipitation-dissolution (Brennan and Lindsay, 1998); ion-pair, complex or chelate formation (McKee and McKevlin, 1993); and nitrification-ammonification (Paul and Clark, 1989). Site disturbance studies have documented chemical reduction and 
increased soil $\mathrm{pH}$ with soil disturbance on poorly-drained soils (Aust and Lea, 1992). Dulohery et al. (1996) measured lower rates of $\mathrm{CO}_{2}$ efflux from trafficked (skidder damage) / bedded soils. This decrease may be attributed to slower organic matter decomposition under anaerobic conditions which is indicative of reducing conditions (Ponnamperuma, 1984; McKee and McKevlin, 1993). Based on the relationships between waterlogging, redox, and soil biological and chemical processes found in other studies, we would expect that soil disturbance during wet-weather harvesting would alter the soil fertility.

Maintenance and enhancement of soil productivity is important to the long-term success of intensive forest management. A simple technique is needed for monitoring the effects of different management practices on soil as the means in developing management codes that foster maintenance and enhancement of soil productivity. A central question is whether management impacts on long-term soil productivity can be assessed. Traditional forest field studies, such as the one reported on by Tiarks and Haywood (1996) and the several reviewed by Morris and Miller (1994), are seldom conclusive with respect to management impacts on long-term productivity. In agriculture, scientists recognized this problem and began to develop soil productivity models nearly 70 years ago (e.g., Storie, 1933) by using soil physical and chemical properties as quality indicators. We argue that the soil quality concepts developed in agriculture should form a good basis for management impact assessment in intensively-managed forest plantations.

Bedding is a common site preparation technique used on wet sites in the southeastern United States. Many studies on bedding wet sites emphasized enhanced soil physical and moisture conditions for tree growth, but they did not separate microsite change from possible macrosite changes in the water table across the bedded area. Some researchers observed a diminution of tree growth rates during stand closure to mid-rotation phases (Cain, 1978; Haywood, 1983; Tiarks, 1983; Wilhite and Jones, 1981), and even a reduced survival rate on bedded sites (Haywood, 1983). These negative effects of bedding may be caused by limited access of roots to soil water during a dry growing season, which can occur at any time throughout the rotation. For given climate conditions, the key factor is the overall surface water level that determines the bedding effect with respect to soil water supply. It is not clear whether bedding will also affect overall surface water table, especially on sites with flat topography and impermeable subsoils. Surface hydrology in wetlands is the dominant factor determining soil physical, chemical and biological processes. In view of the need to maintain both site productivity and wetland functions, it is crucial to understand how overall surface water table reacts to bedding-manipulated site conditions.

Non-crop vegetation is normally seen as competing with the crop-trees for moisture, light and nutrients. However, it has been argued that non-crop vegetation has positive effects on soil properties, processes and forest productivity. There is some evidence that the retention of non-crop herbaceous species may play a role in maintaining long-term productivity, especially in areas where soil has been disturbed by harvesting. Plant roots penetrate soil that has been churned and compacted, improving its structure, and increasing its permeability and aeration (Jastrow and Miller, 1991). Powers et al. (1990) cite management-induced changes in macroporosity and organic matter as primary sources of 
long-term forest decline. Herbaceous root growth and dieback may create root channels that increase macroporosity and improve the soil structure and pore size distribution. With increasing interest in sustainable forestry and biodiversity, more attention is being paid to the long-term and ecosystem-level effects of vegetation management.

Forest industry understands that its economic survival and prosperity is closely tied to its ability to maintain and enhance site productivity. Success in this endeavor depends on understanding how different management practices affect sites positively or negatively, and an ability to employ management strategies to correct both inherent problems and those induced by management. During the past decade, many studies on soil disturbance and bedding mitigation effects have been conducted in the southeast. Overall, however, these studies have experimental designs based on limited operational reality or constrained shortterm effects.

In 1991, we began an operational, rotation-length study located in a wetland area on the Lower Coastal Plain in South Carolina; a region where long-term sustainability concerns center around soil / site disturbances resulting from harvesting timber on wet sites. Our concern is that the common wet-site disturbances, soil compaction, and displacement may have long-term, detrimental effects on the key soil properties and hydrologic processes that determine tree productivity in this region. We are also concerned that the commonly employed site mitigation technology may not ameliorate soil conditions that may have been damaged during wet-site harvesting. Furthermore, we believe that non-crop vegetation may have positive effects on the recovery of disturbed soil and hydrology, and that it may contribute to wetland functions and long-term productivity.

\section{Research Objectives}

This long-range, operationally-scaled research was initiated to address the questions and concerns introduced above. The specific objectives of this study are to:

\section{Basic Research Objectives}

- Identify the determinants of soil, site, and forest productivity for Atlantic coastal plain wetland soils (i. e., decomposition, nutrient supply, and site hydrology) and determine the conditions under which intensive forest management enhances, maintains, or damages long-term soil productivity.

- Determine if wetland functions such as soil productivity and site drainage can be restored, if damaged, and at what rate of recovery.

- Determine the role of subordinate vegetation on soil quality, nutrient cycling, and recovery of disturbed soils. 
- Determine how intensive forest management affects stand carbon cycling over a forest rotation.

\section{Applied Research Objectives}

- Develop soil disturbance hazard ratings for trafficking soils based on their strength, moisture content, and depth to water table.

- Develop a decision support system that predicts the influence of management, both spatially and temporally, on pine yields based on soil, hydrology, and tree growth processes.

- Determine the effectiveness and assess the appropriateness of current best management practices in the context of sustainable forestry initiatives.

\section{Long-Term Project Benefits}

This research project addresses tenable questions in four critical areas:

- Enhancement and protection of soil and forest productivity.

- The effects of intensive silviculture on wetland function and protection.

- The efficiency of energy utilization and the role of plantation forests in the carbon cycle.

- Intensively managed forests as sustainable forestry.

We will identify management-induced soil and site conditions that may limit forest productivity, and we will identify cost-effective environmentally-acceptable options for enhancing soil and forest productivity to realize the full potential of genetically-improved trees. Forest managers and landowners will use this information to adapt their forest management practices, if necessary, to maintain and enhance the productivity and function of their forest sites. Policy makers and regulators charged with protecting the public's environment will use this information as a scientific basis for determining whether best management guidelines and wetland regulations are effective, whether they need to modified, and in some cases whether they are even necessary.

There is much confusion about the role of forestry in implementing the Kyoto Protocol. It is important to properly account for the real carbon benefits that sustainable forestry provides. This research is also designed as a case study for carbon stock accounting on an intensively-managed site over an entire rotation period, the results of which will provide insight into the understanding of wetland carbon sequestration potential and management 
impacts.

Furthermore, the scientific community will transfer and incorporate the results of this and other studies, in a systems-oriented approach for soil resource management to achieve sustained forest productivity, efficient energy utilization, conservation of carbon in soils, and a suitable level of environmental quality. 


\section{RESEARCH APPROACH}

\section{Study Sites}

The study sites are located near Cottageville in Colleton county, South Carolina (Figure 1). At the time of harvesting, the loblolly pine trees were 20 (Site I), 23 (Site II) and 25 (Site III) years old. The sites annually receive $1193 \mathrm{~mm}$ precipitation $(50 \%$ between June and September) and has a mean temperature of $19.0{ }^{\circ} \mathrm{C}$, ranging from $10.1{ }^{\circ} \mathrm{C}$ in January to $27.6{ }^{\circ} \mathrm{C}$ in July. The pine plantations were highly productive, with an average tree height of $23 \mathrm{~m}$ and a mean volume of $371 \mathrm{~m}^{3} \mathrm{ha}^{-1}$. The dominant understory species were sweetgum (Liquidambar styraciflua L.), elms (Ulmus spp.), oaks (Quercus spp.), green ash (Fraxinus


pennsylvanica Marsh.), red maple (Acer rubrum Figure 1. The study is located near L.), and ironwood (Carpinus caroliniana Walt.). Charleston, South Carolina. The US Fish and Wildlife Service wetland inventory system (Cowardin et al., 1979) classifies the site as Palustrine, forested, needle leaved evergreen wetland. The study area is within a lower coastal terrace landscape $(<10$ $\mathrm{m}$ above sea level) with a flat topography (slope $<1 \%$ ).

\section{Treatment Design}

Two forest practice scenarios were conducted at the operational scale: harvesting and site preparation (Figure 2). Trees were clearcut i) when soils were wet, (wet-weather harvesting) and ii) when soils were dry (dry-weather harvesting). The harvested sites were site prepared either as non-bedded, bedded, or mole-plowed plus bedded (Figure 3). The harvest treatment was designed to create a broad gradient of surface soil disturbance, whereas the site preparation treatment was designed to investigate mitigation effects on soil and site drainage. Dry-weather harvesting was installed in the fall of 1993. Wet-weather harvesting was imposed in the spring of 1994. The sites were prepared in November 1995 and planted with loblolly pine seedlings in February 1996. The combination of harvest and site preparation treatments is symbolized as follows: (i) dry flat (dry-weather harvesting without bedding); (ii) dry bed (dry-weather harvesting with bedding); (iii) wet flat (wet-weather harvesting without bedding); (iv) wet bed (wet-weather harvesting with bedding); and (v) wet-weather harvesting with mole-plowing plus bedding (mole-plow + bed). 


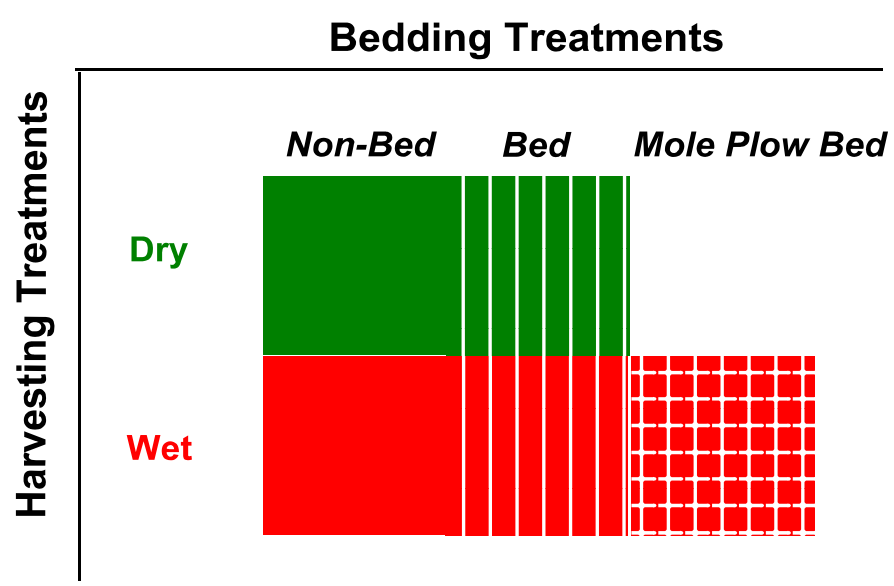

Figure 2. Experimental design including 2 harvesting and 3 site preparation treatments.

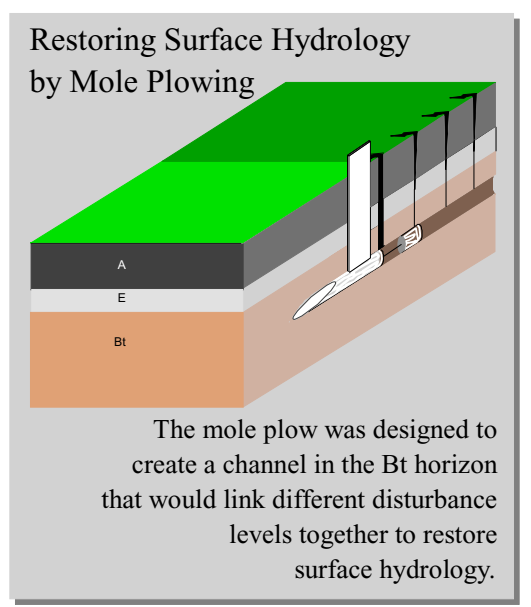

Figure 3. Diagram showing the design of mole-plow treatment.

Harvesting was accomplished using rubber-tired feller-bunchers (Hydro-Axe 411, Blount Inc., Owatonna, Minnesota, USA; Franklin 105, Franklin Equipment, Franklin, Virginia, USA) and medium-sized grapple skidders (Franklin 170; Caterpillar 518, Caterpillar Inc., Peoria, Illinois, USA; Timberjack 450C, Timberjack Group, Helsinki, Finland) with $81.3 \mathrm{~cm}$ wide tires exerting an inflation pressure between 207 and $241 \mathrm{kPa}$. All harvested plots were aerially-sprayed with a mix of Arsenal (American Cyanamid Co., New Jersey, USA) and Accord (Monsanto Company, Montana, USA) in late July, 1995 to reduce competition. Bedding at a $3 \mathrm{~m}$ spacing was performed in November, 1995, using a 6-disc bedding plow equipped with $91.4 \mathrm{~cm}$ discs (Model 110, Savannah Forestry Equipment Inc., Savannah, Georgia, USA). For the mole-plow treatment, a $10 \mathrm{~cm}$ diameter channel was created at a 70$80 \mathrm{~cm}$ depth on a $20 \mathrm{~m}$ by $20 \mathrm{~m}$ grid by using a deep plow harrow device consisting of a $1 \mathrm{-m}$ long shank and 50-cm plow. The bedding harrow and mole-plow were pulled with a Caterpillar D-8 tractor.

\section{Measurement design}

\section{At the operational scale}

A $20 \mathrm{~m}$ x $20 \mathrm{~m}$ grid system was laid out across the three 20-ha plantations. On each of these grid points (in total, 1409), the following measurements were conducted:

- surface elevation survey before and after harvesting

- monthly water table measurement

- soil litter layer biomass and carbon storage

- $\quad$ soil physical and hydraulic properties before and after harvesting

- soil surface disturbance survey after harvesting

- tree growth measurement before harvesting and at age 2 on a 1/125-ha sample plot centered on each grid point. 
Surface soil disturbances were visually classified as (i) non-disturbed, (ii) compressed, (iii) shallow-rutted $(<20 \mathrm{~cm}$ ), (iv) deep-rutted $(>20 \mathrm{~cm})$, and (v) churned (Figure 4). A climatic station measuring relevant weather parameters such as air temperature, humidity, precipitation, and radiation, was installed to represent climate conditions for all the 3 plantations.

\section{Bioassay plots}

Fifty four $2.1 \mathrm{~m} \times 6.3 \mathrm{~m}$ bioassay plots were established in a combination of harvest treatment $x$ site preparation treatment $x$ surface soil disturbance. In the bioassay plots, pine trees were planted at a dense $30-\mathrm{by}-30 \mathrm{~cm}$ spacing to accelerate early competition of trees for soil water and nutrient resources. Soil quality indicators including soil physical, chemical and hydraulic properties were measured. In addition, the biological processes including organic matter decomposition, nitrogen mineralization, and soil respiration, were monitored monthly over one year.
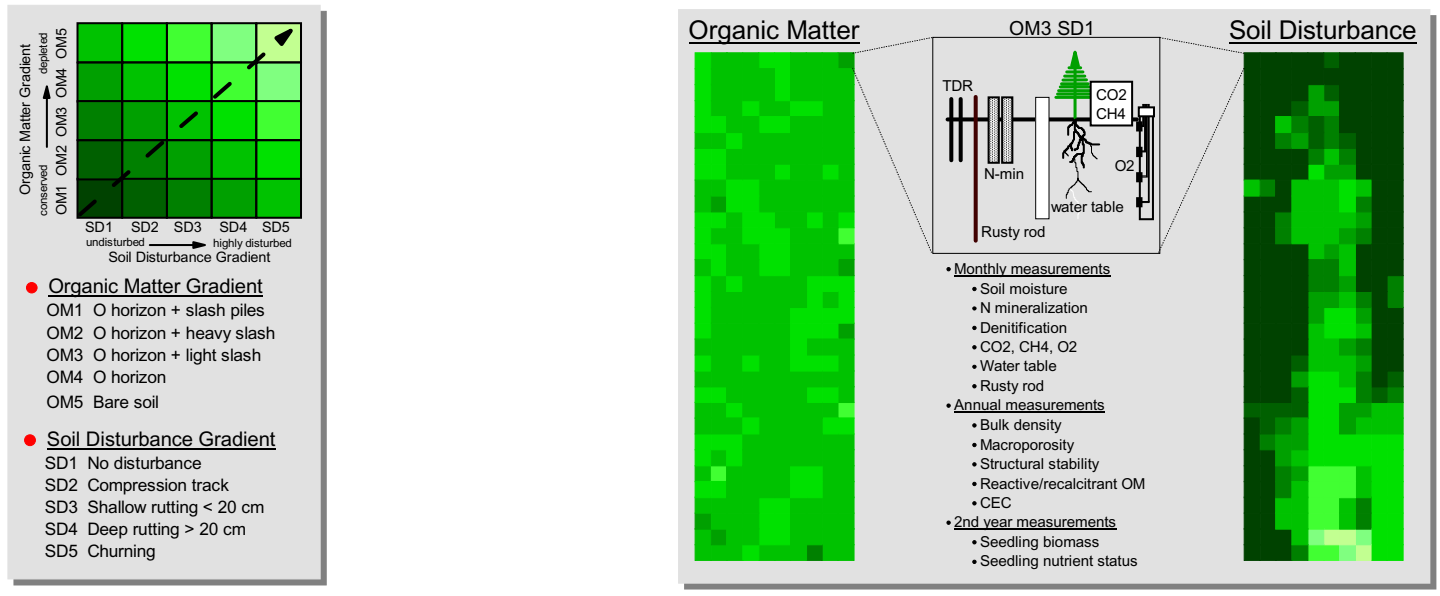

Figure 4. Matrix of organic matter and soil disturbance gradient (left), and soil quality indicators being measured.

Bioassay plots were designed to test the combined effect of organic harvest residue removal and soil physical disturbance on pine growth. The design defines a five by five response matrix replicated three times, one per plantation (Figure 4, left). The soil quality indicators were measured for each cell in the soil organic matter - soil disturbance matrix in the non-site prepared plots (Figure 4, right).

\section{Vegetation plots}

Prior to harvest, all hardwood and understory species were taxonomically identified. The pre-harvest vegetation community was characterized based on the dominance of each species. In addition, an average pre-harvest prevalence index was determined to assess if the study sites met the hydrophytic vegetation criterion for jurisdictional wetland classification. 


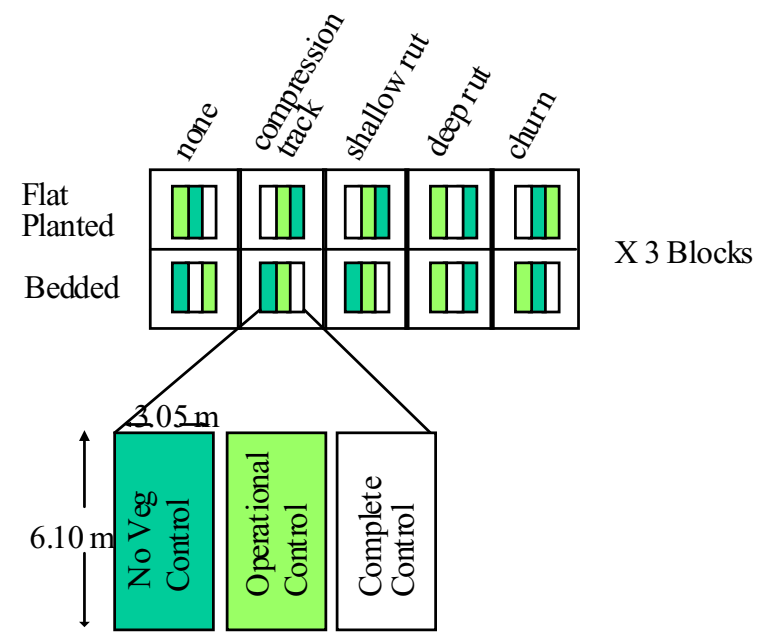

Vegetated: No herbicide applied

Operational Control: Aerial application of Oust (Sulfometuron-methyl) and Escort (Metsulfuron-methyl)

Veg Free: Operational control and additional back-pack sprayed applications of Glyphosate

Figure 5. 2 × 3 factorial with vegetation split plots within a randomized complete block design.

After harvest, $3.05 \mathrm{~m} \times 6.1 \mathrm{~m}$ vegetation treatment plots were established (Figure 5), in the same fashion as bioassay plots, in a combination of harvest treatment $\mathrm{x}$ site preparation treatment $x$ surface soil disturbance. Total aboveground biomass and biomass of dominant species were recorded at three month intervals. Post harvest dominant species were determined based on the "50/20 rule" for wetland species classification. Soil physical and biological properties and processes were measured including bulk density, saturated hydraulic conductivity, macroporosity, aggregate stability, aeration depth, soil microbial biomass carbon, and nitrogen mineralization. 


\section{RESULTS SUMMARY}

\section{Site Conditions and Mensurational Characteristics ${ }^{[22,24,28]}$}

Soils of the study sites are derived from Oligocene and Pleistocene marine and fluvial deposits. Two predominant soil series, Argent loam and Santee loam, are among hydric soils within the Alfisol order. Soils show a sequence of A-E-Btg horizons with a large variation in depths: from 0 to $51 \mathrm{~cm}(13 \mathrm{~cm}$ on average) for the sandy loam textured A-horizon and from 0 to $81 \mathrm{~cm}$ ( $15 \mathrm{~cm}$ on average) for the E-horizon with the same soil texture. Bulk density and saturated hydraulic conductivity vary greatly across the horizons (all values in median followed by ranges): $1.10 \mathrm{~g} \mathrm{~cm}^{-3}\left(0.68-1.67 \mathrm{~g} \mathrm{~cm}^{-3}\right)$ and $7.71 \mathrm{~cm} \mathrm{hr}^{-1}\left(0.00-99.99 \mathrm{~cm} \mathrm{hr}^{-1}\right)$ for the A-horizon; $1.66 \mathrm{~g} \mathrm{~cm}^{-3}\left(1.20-1.87 \mathrm{~g} \mathrm{~cm}^{-3}\right)$ and $0.175 \mathrm{~cm} \mathrm{hr}^{-1}\left(0.00-23.67 \mathrm{~cm} \mathrm{hr}^{-1}\right)$ for the E-horizon, respectively. The sandy clay texture Btg-horizon that can appear from the soil surface is massively compacted with a bulk density (median) of $1.51 \mathrm{~g} \mathrm{~cm}^{-3}\left(0.93-1.81 \mathrm{~g} \mathrm{~cm}^{-3}\right)$ and a saturated hydraulic conductivity (median) of $0.00 \mathrm{~cm} \mathrm{hr}^{-1}\left(0.00-7.09 \mathrm{~cm} \mathrm{hr}^{-1}\right)$. Average water table depths during the winter period were high, ranging from 6 to $10 \mathrm{~cm}$ near soil surface at the study sites (Table 1). During the summer period, water table dropped to 48 $57 \mathrm{~cm}$.

Table 1. Hydrologic conditions and mensurational characteristics of 3 studied wetland pine forests.

\begin{tabular}{lcccccccc}
\hline Site & \multicolumn{2}{c}{ Water Table } & \multicolumn{3}{c}{ Pine } & \multicolumn{3}{c}{ Hardwood } \\
\cline { 2 - 8 } & $\begin{array}{c}\text { Winter } \\
(\mathrm{cm})\end{array}$ & $\begin{array}{c}\text { Summer } \\
(\mathrm{cm})\end{array}$ & $\begin{array}{c}\text { Density } \\
\left(\mathrm{n} \mathrm{ha}^{-1}\right)\end{array}$ & $\begin{array}{c}\text { BA } \\
\left(\mathrm{m}^{2} \mathrm{ha}^{-1}\right)\end{array}$ & $\begin{array}{c}\text { Height } \\
(\mathrm{m})\end{array}$ & $\begin{array}{c}\text { Density } \\
\left(\mathrm{n} \mathrm{ha}^{-1}\right)\end{array}$ & $\begin{array}{c}\text { BA } \\
\left(\mathrm{m}^{2} \mathrm{ha}^{-1}\right)\end{array}$ & $\begin{array}{c}\text { Height } \\
(\mathrm{m})\end{array}$ \\
\hline I & 10 & 57 & 842 & 40.54 & 22.4 & 130 & 1.17 & 10.2 \\
II & 6 & 54 & 521 & 36.22 & 24.0 & 452 & 4.30 & 10.7 \\
III & 8 & 48 & 638 & 38.92 & 23.8 & 235 & 2.22 & 10.6 \\
\hline
\end{tabular}

Stand density was different among the three pine plantations (Table 1) mainly due to a thinning procedure conducted on Site II (23 years old) and III (25 years old) in 1980. Site I (20 years old) was never thinned and the reduction of the original stocking (1666 trees ha ${ }^{-1}$ ) at the site was due to early survival and later self thinning. Tree heights and basal areas among the 3 sites, however, were not significantly different. Apparently, thinning affected hardwood invasion in the pine stands by showing that the density and basal area of hardwoods increase with decreasing pine density. 


\section{Pre-Harvest Biomass and Nutrient Pools ${ }^{[22]}$}

The three wetland pine plantations were highly productive. Total aboveground biomass of pine trees were $212,964,207,557$, and $220,830 \mathrm{~kg} \mathrm{ha}^{-1}$ for Site I, II and III, respectively (Table 2). The dry weight of inside stemwood ranged from 155,453 to $167,495 \mathrm{~kg} \mathrm{ha}^{-1}$, making up about $75 \%$ of the total aboveground biomass. The dry weight of bark was between 24,004 and $26,242 \mathrm{~kg} \mathrm{ha}^{-1}$, adding another $12 \%$ of the total biomass to the amount that will be removed following a conventional (stem-only) harvest. The dry weights of branch $(18,164$ $\left.-19,812 \mathrm{~kg} \mathrm{ha}^{-1}\right)$ and foliage $\left(8,359-8,288 \mathrm{~kg} \mathrm{ha}^{-1}\right)$ contributed to about $9 \%$ and $5 \%$ of the total biomass, respectively, which are a potential source of harvest residue.

Table 2. Biomass of pine components in three wetland loblolly pine plantations.

\begin{tabular}{lccccc}
\hline Sites & Stem & Bark & Branch & Foliage & $\Sigma$ \\
\cline { 2 - 4 } & & & & & \\
\cline { 2 - 6 } & & & & & \\
\cline { 4 - 6 } I & 159984 & 26242 & 18164 & 8574 & 212964 \\
& $(75)$ & $(12)$ & $(9)$ & $(4)$ & $(100)$ \\
II & 155453 & 24005 & 19812 & 8288 & 207557 \\
& $(75)$ & $(12)$ & $(10)$ & $(4)$ & $(100)$ \\
III & 167495 & 25687 & 19289 & 8359 & 220830 \\
& $(76)$ & $(12)$ & $(9)$ & $(4)$ & $(100)$ \\
\hline
\end{tabular}

* Numbers in parentheses are percent of each tree component in total biomass

Total aboveground biomass of the understory hardwoods $(\mathrm{dbh}>2.54 \mathrm{~cm})$ were very different among the study sites due to the different densities. The 23-yr-old stand (Site II) with the lowest pine density (521 stems ha ${ }^{-1}$, Table 3 ) showed the highest understory hardwood biomass $\left(16,369 \mathrm{~kg} \mathrm{ha}^{-1}\right)$, while the 20 -yr-old stand (Site I) with the highest pine density $\left(842\right.$ stems ha $\left.^{-1}\right)$ presented the lowest undersory hardwood biomass $\left(4,445 \mathrm{~kg} \mathrm{ha}^{-1}\right)$.

Table 3. Biomass of understory hardwood species in three wetland loblolly pine plantations.

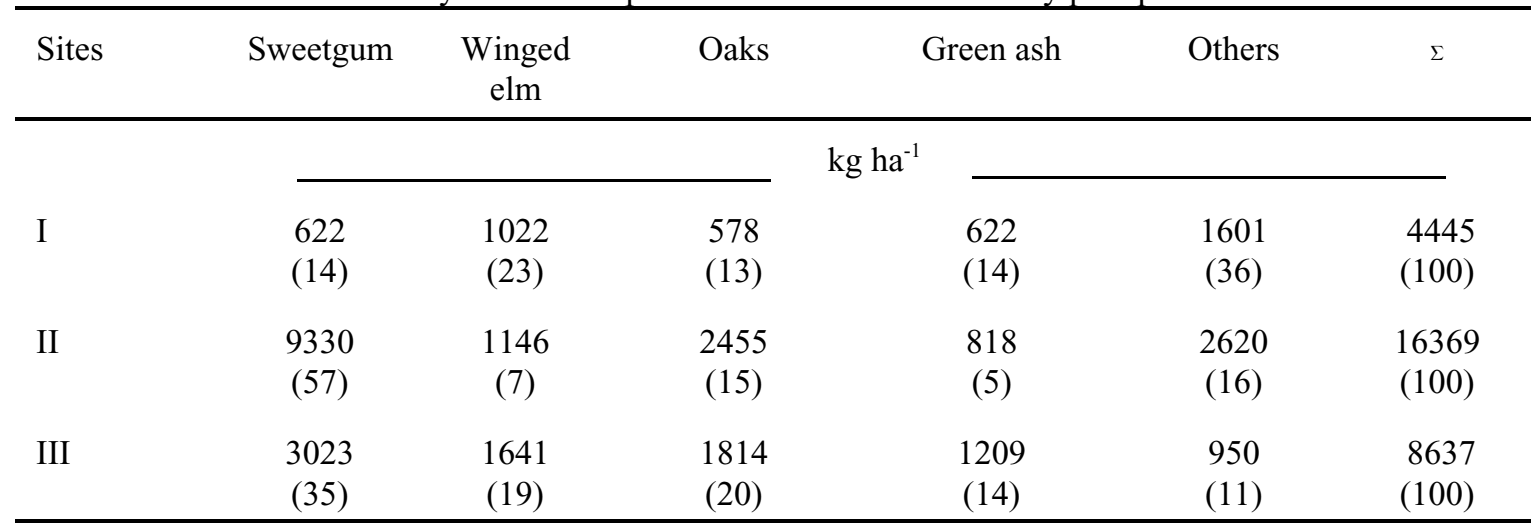


On average, the plantations stored 103,963 C, 478 N, 63 P, $312 \mathrm{~K}, 220 \mathrm{Ca}$, and $93 \mathrm{~kg} \mathrm{ha}{ }^{-}$ ${ }^{1}$ in their aboveground pine biomass (Table 4). Due to the large biomass quantity, stemwood contained about $75 \% \mathrm{C}, 47 \% \mathrm{~N}, 51 \% \mathrm{P}, 52 \% \mathrm{~K}, 44 \% \mathrm{Ca}$, and $52 \% \mathrm{Mg}$ of the total amounts of these nutrients. Pine bark presented the second largest nutrient pool storing about $12 \% \mathrm{C}$ and similar percentage $(22-25 \%) \mathrm{N}, \mathrm{P}, \mathrm{K}, \mathrm{Ca}$ and $\mathrm{Mg}$, while branch and foliage together contained about $13 \% \mathrm{C}, 31 \% \mathrm{~N}, 25 \% \mathrm{P}, 23 \% \mathrm{~K}, 32 \% \mathrm{Ca}$, and $23 \% \mathrm{Mg}$. Within the pine crown, foliage contained a higher amount of $\mathrm{N}$, a lower amount of $\mathrm{Ca}$, and similar amounts of $\mathrm{P}, \mathrm{K}$, and $\mathrm{Mg}$ compared to branch.

Table 4. Nutrient pools of aboveground pine biomass in three wetland loblolly pine plantations.

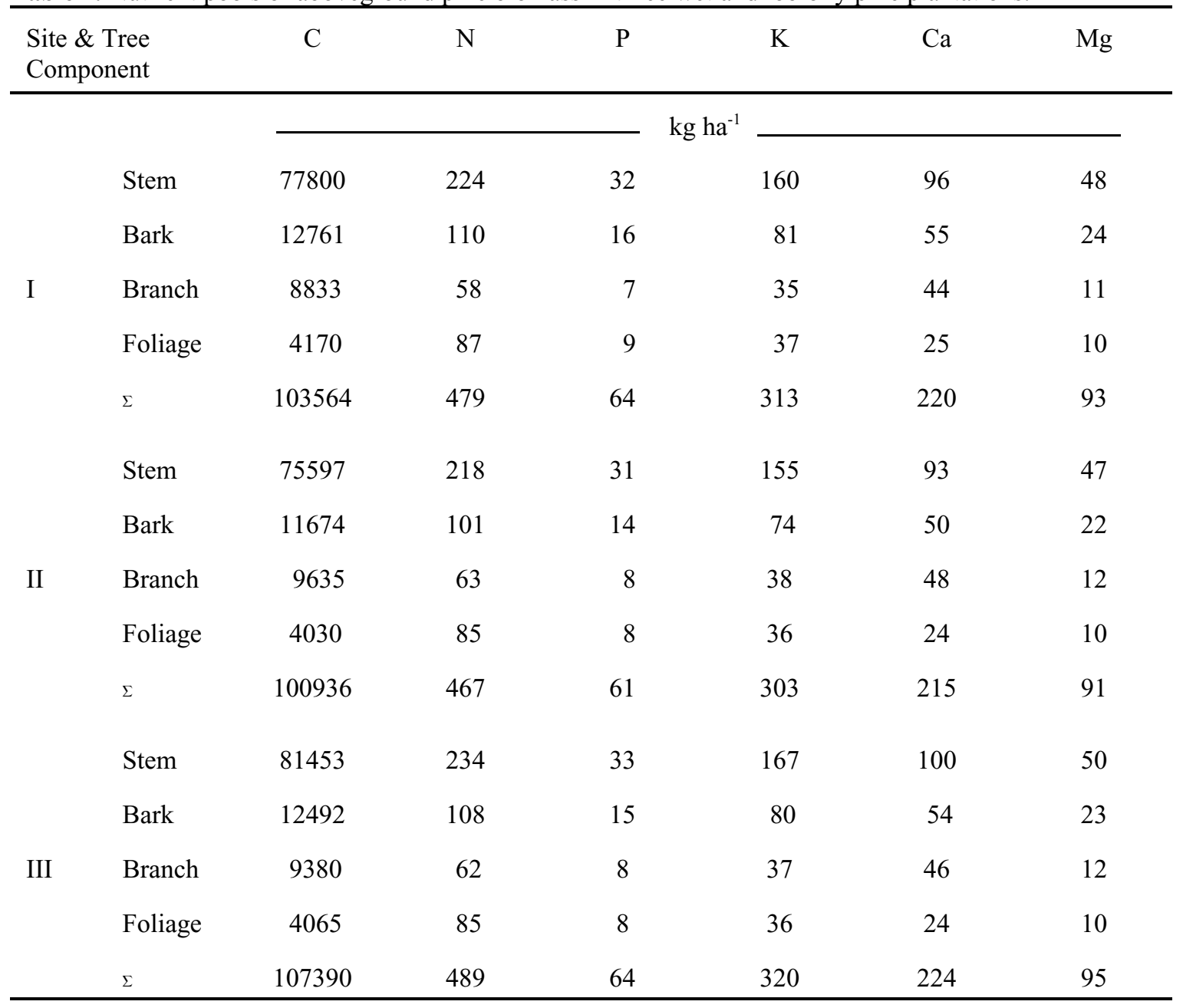




\section{Trafficability and Soil Disturbance ${ }^{[1,19,24]}$}

Trafficking during timber harvest can cause surface soil disturbances. When soils are wet, harvesting can cause an excessive surface disturbance, as evidenced by our study that on average, $77 \%$ of the wet-weather harvested sites were compressed, rutted, puddled or churned, whereas $92 \%$ of the dry-weather harvested sites remained undisturbed (Figure 6). On the wet-weather-harvested sites, saturated hydraulic conductivity, macroporosity, and total porosity decreased $72 \%, 44 \%$, and $8 \%$, respectively, and bulk density increased $19 \%$. In contrast, the changes of these properties on the surface of the dry-weather harvested sites were much smaller (in the same arrangement and direction): $6 \%, 3 \%, 1 \%$, and $2 \%$.

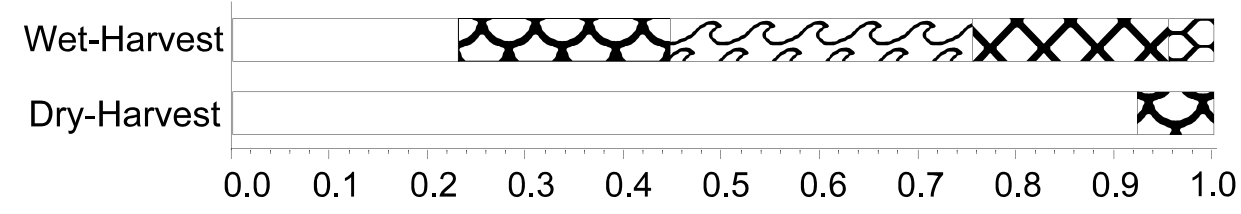

Disturbance Distribution in Percent

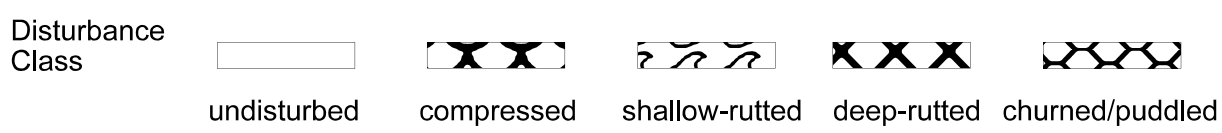

Figure 6. Surface soil damage following harvesting three wetland pine plantations under wet-weather and dryweather conditions.

Apart from differences in machine types and loggers' experience, the degree and extent of harvest trafficking effect on surface disturbance vary with soil and moisture conditions. Harvesting hazard can be minimized by traffic to soils with a volumetric water content less than $25 \%$, a point at which soil strength is adequate to minimize soil deformation (Figure 7 ).

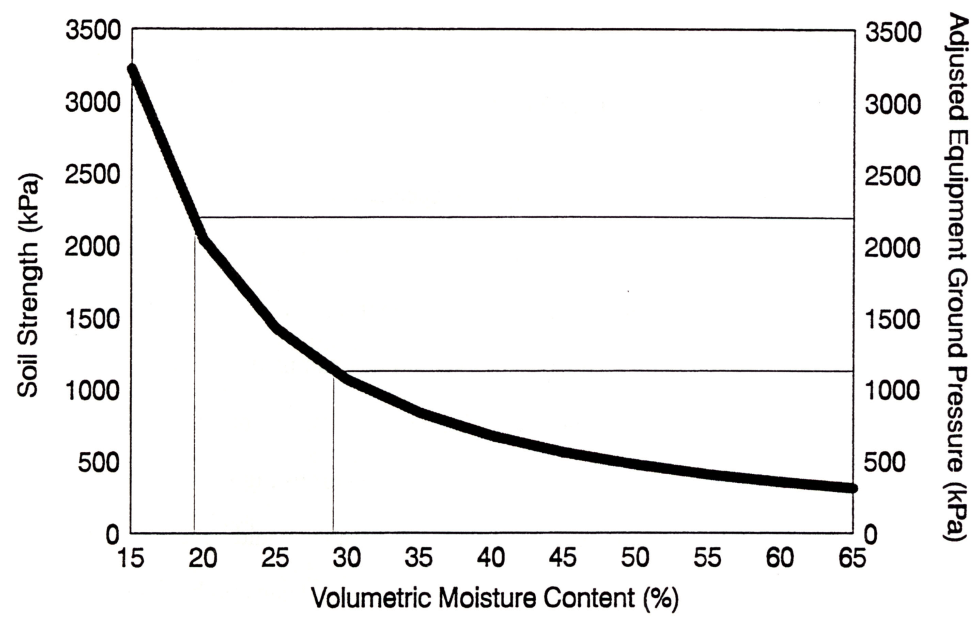

Figure 7. Trafficability as a function of soil water content. 


\section{Hydrologic Response to Harvesting ${ }^{[19,20,28,52]}$}

On monthly averages, surface water tables in the 3 plantations showed a large fluctuation from a saturation above surface to an unmeasurable water table depth at $90 \mathrm{~cm}$. Water table was highest from December to March $(<35 \mathrm{~cm})$ and lowest from April to May $(>65 \mathrm{~cm})$. This seasonal fluctuation in the water table depth is largely reflected by seasonal evapotranspiration which, on an annual basis, counts about $70 \%$ of the precipitation at the study site.

Because of the strong effect of evapotranspiration on the site hydrology, removal of pine trees elevated the overall surface water table to about $40 \mathrm{~cm}$ during the growing season compared to the uncut control (data not presented). The elevation in water tables was different between the two harvesting treatments (Table 5). During a one-year post-harvest period (July 1994 - July 1995), overall water table depths were elevated $14 \mathrm{~cm}$ for the dry-weather harvested sites and $21 \mathrm{~cm}$ for the wet-weather harvested sites compared to the uncut control plots. The difference in water table elevation between the two harvest treatments was very small during the dormant season $(<2 \mathrm{~cm})$, but large during the growing season $(>10 \mathrm{~cm})$, indicating a strong impact of wet-weather harvest on overall water table primarily through disturbing transpiring ground vegetation rather than soil physical and hydraulic properties in wet flats.

Table 5. Elevation in surface water table depths compared to uncut control references as effected by harvesting and site preparation treatments.

\begin{tabular}{|c|c|c|c|c|c|}
\hline \multirow[t]{2}{*}{ Treatment } & & \multicolumn{4}{|c|}{ Elevation in Water Table Depths } \\
\hline & & Post Harvest & $\begin{array}{l}\text { Post Site } \\
\text { Preparation }\end{array}$ & 1. Year & 2. Year \\
\hline \multirow[t]{2}{*}{ Dry-Harvest } & Non-Bed & $14 b$ & $43 a$ & $28 \mathrm{~b}$ & $14 a b$ \\
\hline & Bed & & $28 b$ & $25 b$ & $13 b$ \\
\hline \multirow{3}{*}{$\begin{array}{l}\text { Wet- } \\
\text { Harvest }\end{array}$} & Non-Bed & & $45 a$ & $36 a$ & $21 a$ \\
\hline & Bed & $21 a$ & $27 b$ & $28 b$ & $16 a b$ \\
\hline & Plow\&Bed & & $27 b$ & $30 \mathrm{~b}$ & $18 a b$ \\
\hline
\end{tabular}

$¥$ Post Harvest = July 1994 - July 1995; Post Site Preparation = February - April 1996; 1. Year following planting = May 1996 -April 1997; 2. Year following planting = May 1997 - April 1998.

$¥$ Means followed by the same letter within a column are not significantly different at the 0.1 level.

Trafficking during wet-weather harvesting greatly changed the microsite soil surface by rutting, causing a large microsite spatial heterogeneity in wetness and drought (Figure 8). The size and duration of wet-dry period on the wet-weather-harvested sites were profound 
compared to that on the dry-weather-harvested sites. This microsite mosaic of surface water table remained over the two years following stand establishment, which may have long-term effects on stand-level pine productivity and patchiness of wetland vegetation communities.

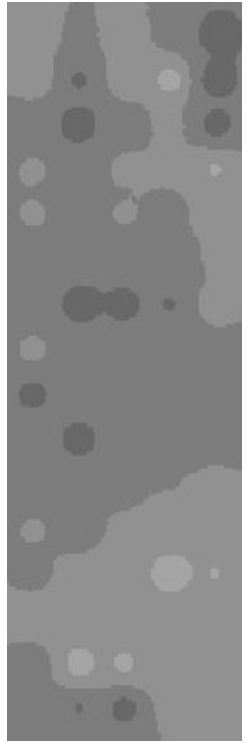

Pre-Harvest

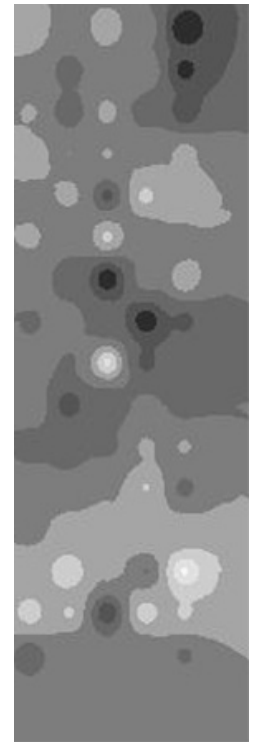

Post-Harvest

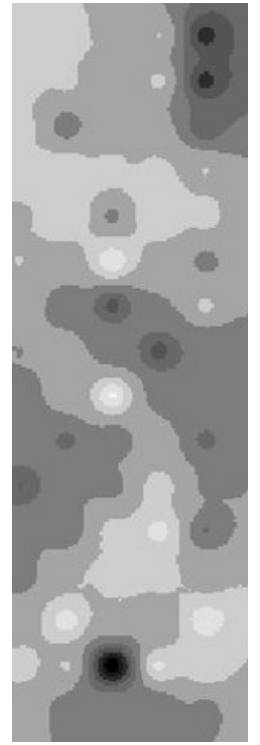

Stand Establishment
Water Table

(cm)

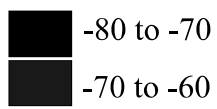

-60 to -50

-50 to -40

-40 to -30

-30 to -20

-20 to -10

-10 to 0

0 to 10

10 to 20

Figure 8. Wet-weather harvesting causes a large spatial heterogeneity in surface water table.

\section{Hydrologic Response to Site Preparation ${ }^{[19,20,21]}$}

Bedding, both conventional and mole-plow bedding, initially lowered overall surface water table depths on the dry-weather and wet-weather harvested sites. During the short postsite preparation period (end of February - beginning of April, 1996), the bedded sites showed a 15-18 cm lower water table depth than the non-bedded sites (Table 5). However, in the following two years after tree planting, both conventional bedding and mole-plowing plus bedding did not prove to have a lasting effect in lowering overall surface water table. Throughout stand establishment, the water table elevation was higher on the wet-weather harvested sites than on the dry-weather harvested sites with or without bedding treatments (Table 5). Although this elevation difference was not statistically significant, the trend suggests a faster recovery of surface hydrology on the dry-weather harvested sites with minimal surface soil disturbances.

Although overall water table level was little affected by bedding, microsite soil water conditions were strongly manipulated by this tillage practice. Bedding changes microsite topography in mounding beds at the expense of soil volume loss in inter-bed zones. The lowered areas provide a large space for water storage, causing them to be inundated during a long period of the year (Figure 9, left). The initial difference in water table between the top and the bottom of a bed was large during the first few months following bedding (Figure 9, 
right). The difference decreased rapidly and held at a level with a fluctuation of mostly less than $10 \mathrm{~cm}$, as shown in Figure 9 (right), an example from one of the bedded sites. This difference in water level and its fluctuation determine arable soil surface and volume through time, and thus are decisive to early pine survival and growth and soil biological processes.
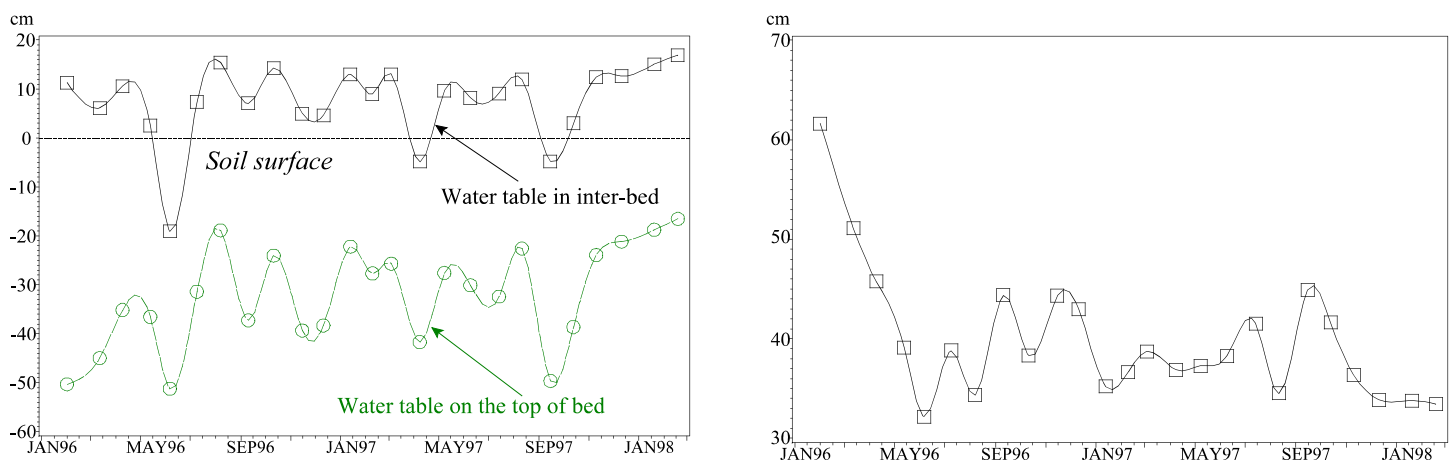

Figure 9. Water table dynamics on (left) and the difference between bed and inter-bed over time (right).

\section{Early Pine Growth Responses to Soil Disturbance and Site Preparation ${ }^{[8,19]}$}

No significant difference in tree growth among undisturbed, compressed, and shallowrutted areas was found on non-bedded, bedded, and mole-plowed \& bedded sites at commercial spacing $(2 \mathrm{~m} \times 3 \mathrm{~m})$ (Table 6$)$. Nor was there a surface soil disturbance effect on early pine growth in the bioassay plots with a dense spacing $(30 \mathrm{~cm} \times 30 \mathrm{~cm})$ (Table 7$)$. Deeprutting and churning seemed to promote early pine growth on the flat-planted sites by showing the highest growth rates in aboveground biomass, tree height, and DBH. On the bedded sites (both conventional and mole-plowing plus bedded), however, the deep-rutted and churned areas exhibited the lowest growth rates.

Table 6. Early pine growth responses to harvest-induced soil disturbances on non-bedded (Flat), bedded (Bed), and mole-plowed/bedded (MPB) sites at spacing $2 \mathrm{~m} \times 3 \mathrm{~m}$.

\begin{tabular}{|c|c|c|c|c|c|c|c|c|c|}
\hline \multirow{3}{*}{$\begin{array}{l}\text { Disturbance } \\
\text { Class }\end{array}$} & \multicolumn{3}{|c|}{ Height } & \multicolumn{3}{|c|}{$\mathrm{DBH}$} & \multicolumn{3}{|c|}{ Aboveground Biomass } \\
\hline & Flat & Bed & MPB & Flat & Bed & MPB & Flat & Bed & MPB \\
\hline & \multicolumn{6}{|c|}{$\mathrm{cm}$} & \multicolumn{3}{|c|}{$\mathrm{g} \mathrm{Tree}^{-1}$} \\
\hline SD1 & $138.3 \mathrm{a}$ & $192.3 \mathrm{a}$ & $216.3 \mathrm{a}$ & $1.1 \mathrm{ab}$ & $1.7 \mathrm{a}$ & $1.9 \mathrm{a}$ & $238.2 \mathrm{~b}$ & $634.2 \mathrm{a}$ & $856.6 \mathrm{a}$ \\
\hline SD2 & $130.1 \mathrm{a}$ & $199.5 \mathrm{ab}$ & $209.0 \mathrm{a}$ & $1.0 \mathrm{~b}$ & $1.8 \mathrm{a}$ & $1.9 \mathrm{a}$ & $227.6 \mathrm{~b}$ & $692.8 \mathrm{a}$ & $838.5 \mathrm{a}$ \\
\hline SD3 & $126.9 \mathrm{a}$ & $186.7 \mathrm{ab}$ & $210.8 \mathrm{a}$ & $1.1 \mathrm{ab}$ & $1.6 \mathrm{a}$ & $1.9 \mathrm{a}$ & $245.8 \mathrm{~b}$ & $602.2 \mathrm{a}$ & $851.9 \mathrm{a}$ \\
\hline SD4 & $140.6 \mathrm{a}$ & $168.3 \mathrm{~b}$ & $184.6 \mathrm{~b}$ & $1.2 \mathrm{a}$ & $1.5 \mathrm{a}$ & $1.7 \mathrm{~b}$ & $319.8 \mathrm{a}$ & $526.1 \mathrm{a}$ & $678.3 b$ \\
\hline
\end{tabular}

$¥$ Disturbance classes based on a visual surface survey following harvesting: SD1 = non-disturbance; SD2= compression; SD3=shallow rutting $(<20 \mathrm{~cm})$; and SD4=deep rutting $(>20 \mathrm{~cm})$ and churning.

$\ddagger$ Means followed by the same letter within a column are not significantly different at the 0.1 level. 
Table 7. Early pine growth responses to soil disturbance and site preparation.

\begin{tabular}{|c|c|c|c|c|}
\hline \multirow{2}{*}{$\begin{array}{l}\text { Site Preparation } \\
\text { Treatment }\end{array}$} & & Undisturbed & Shallow Rut & Churned \\
\hline & & & \multicolumn{2}{|c|}{$\mathrm{kg} \mathrm{m}^{-2}$} \\
\hline None & $0.49 \mathrm{c} \dagger$ & $0.47 \mathrm{bB}+$ & $0.21 \mathrm{bB}$ & $0.78 \mathrm{bA}$ \\
\hline Dry / Bed & $1.29 \mathrm{ab}$ & $1.29 \mathrm{a}$ & -- & -- \\
\hline Wet / Bed & $1.09 \mathrm{~b}$ & $1.03 \mathrm{a}$ & $1.03 \mathrm{a}$ & $0.91 \mathrm{ab}$ \\
\hline Mole / Bed & $1.57 \mathrm{a}$ & $1.78 \mathrm{a}$ & $1.78 \mathrm{a}$ & $1.59 \mathrm{a}$ \\
\hline
\end{tabular}

The results of early pine response to harvesting and site preparation treatments are consistent at both the stand level and dense bioassay level, strongly implying that soil disturbance will not have long-term effects on pine growth. However, excessive surface disturbance such as deep-rutting and churning appeared to diminish bedding quality, causing lower pine biomass production. Re-measurement at stand age 5 will provide a better test of harvesting impacts on the growth.

\section{Soil Quality Index Model ${ }^{[3,4,7,25]}$}

A Soil Quality Index (SQI) model was developed to measure three key attributes of forest soils in promoting i) root growth, ii) air/water balance, and iii) soil fertility. Sufficiency levels of field-measured indicator variables from the 54 bioassay plots were substituted for each attribute and used to calculate the SQI. Based on the two-year pine growth in the bioassay plots, it appeared that (i) surface soil compaction and deep rutting reduced SQI and (ii) retention of organic debris increased SQI. Overall, there were good relationships between early pine aboveground biomass production and SQI $\left(r^{2}=0.73\right)$ in the bioassay plots (Figure 10).

The model was calibrated using tree growth data from the bioassay plots in which pine trees were planted in a dense spacing $(30 \mathrm{~cm} \times 30 \mathrm{~cm})$. The application of the model at stand level with commercial spacing $(2 \mathrm{~m} \times 3 \mathrm{~m})$ did not show the soil disturbance effect on the aboveground biomass productivity. Certainly, the SQI model needs to be further tested using growth data at later ages outside the bioassay plots at the study sites as well as from other sites with different soil and water table conditions. Nonetheless, the agreement of modeled and measured biomass response suggests that the model will do an acceptable job of estimating soil quality as a function of disturbance. 


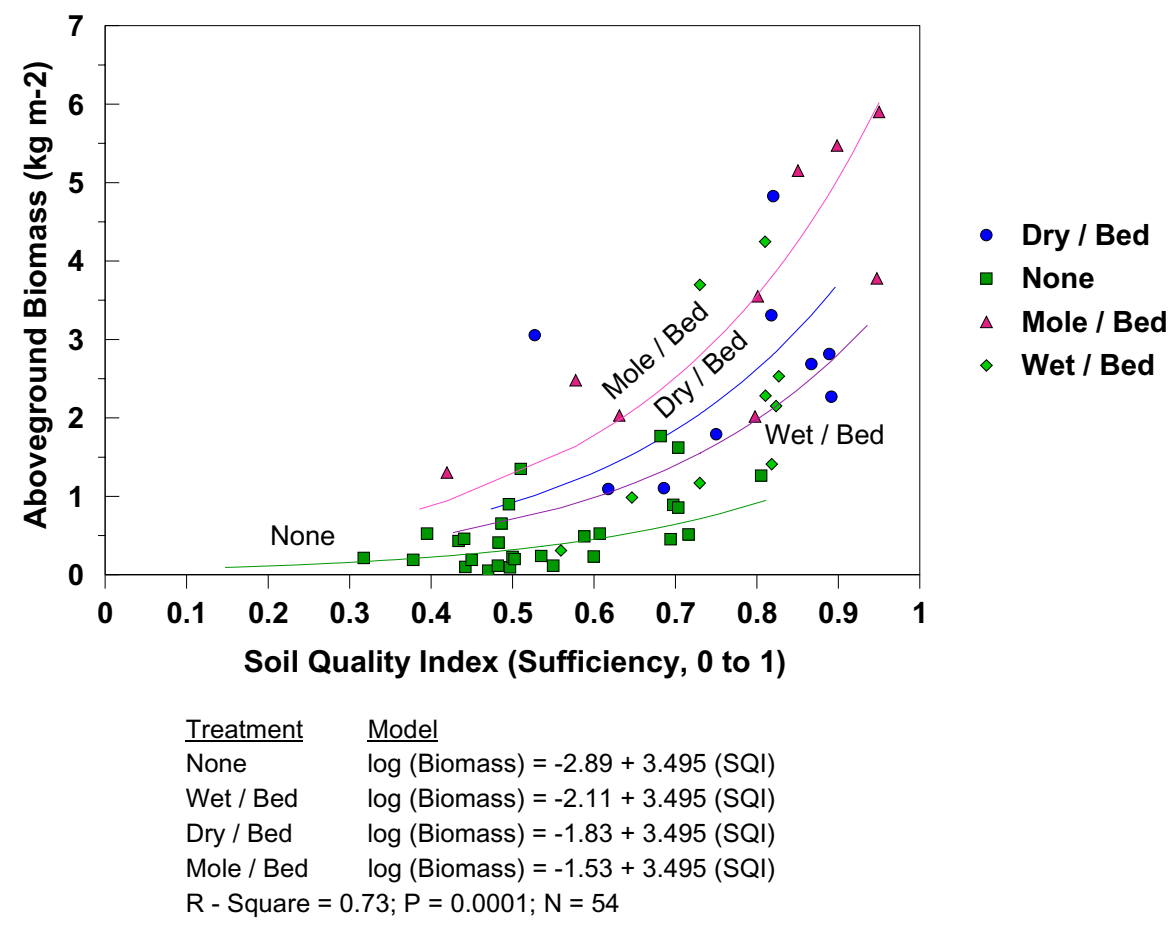

Figure 10. Aboveground biomass as a function of Soil Quality Index (SQI).

\section{Carbon Sequestration and Changes ${ }^{[22,23,49]}$}

Prior to harvesting, the pine plantations contained over 200 tons carbon per hectare. About $60 \%$ of the total system carbon was stored in pine biomass (Figure 11), showing the importance of maintaining forest productivity for carbon sequestration. Harvest and site preparation can greatly manipulate carbon pools in this pine plantation, causing a transfer of 30-ton-per-ha $\mathrm{C}$ to surface soils, which could be a significant carbon sink if managed properly.
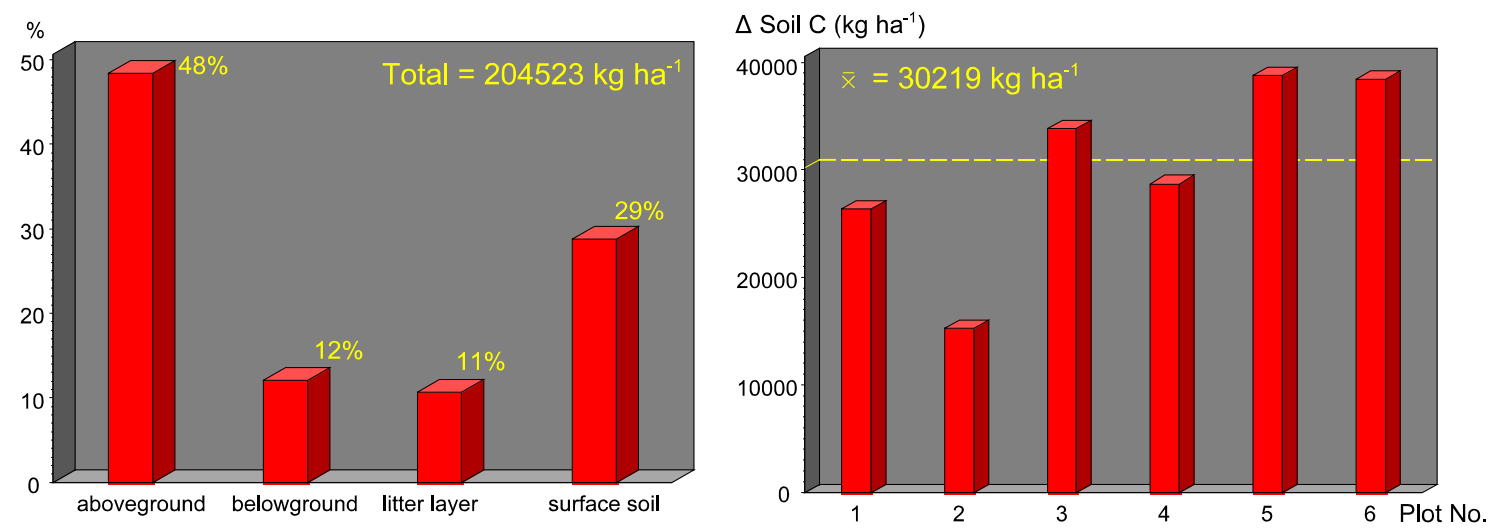

Figure 11. System carbon distribution (left) and changes in soil carbon following harvesting and site preparation. 


\section{Vegetation Dynamics and Wetland Criteria ${ }^{[13,14,15,26]}$}

Prior to harvest, dominant understory hardwoods included sweetgum, winged elm, ash, and oak species. Grass and grass-like species dominated following harvesting with soft rush (Juncus effusus) predominating. Woody species, however, were most prevalent among the dominant species in the undisturbed flat planted treatment areas, and both disturbance and bedding significantly reduced the proportion of woody species (Figure 12).
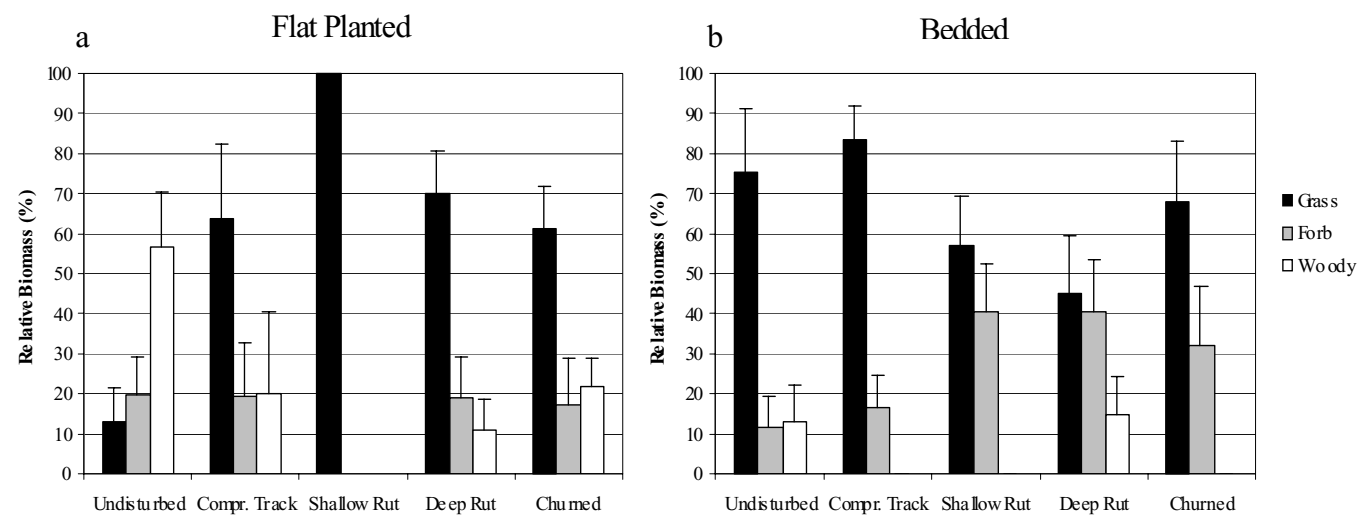

Figure 12. Effects of soil disturbance and site preparation on no-crop vegetation.

Surface soil disturbances such as rutting and churning caused by harvest favored the growth of obligate wetland species, whereas site preparation increased the proportion of facultative wetland species (Figure 13). Prior to harvest, the average wetland prevalence index was 3.03, which is slightly above the hydrophytic plant criterion $(\mathrm{PI} \leq 3)$ (Figure 14). After harvesting, the average prevalence index was 2.49. No significant differences were found among the disturbance, site preparation, and vegetation control treatments for wetland species prevalence.
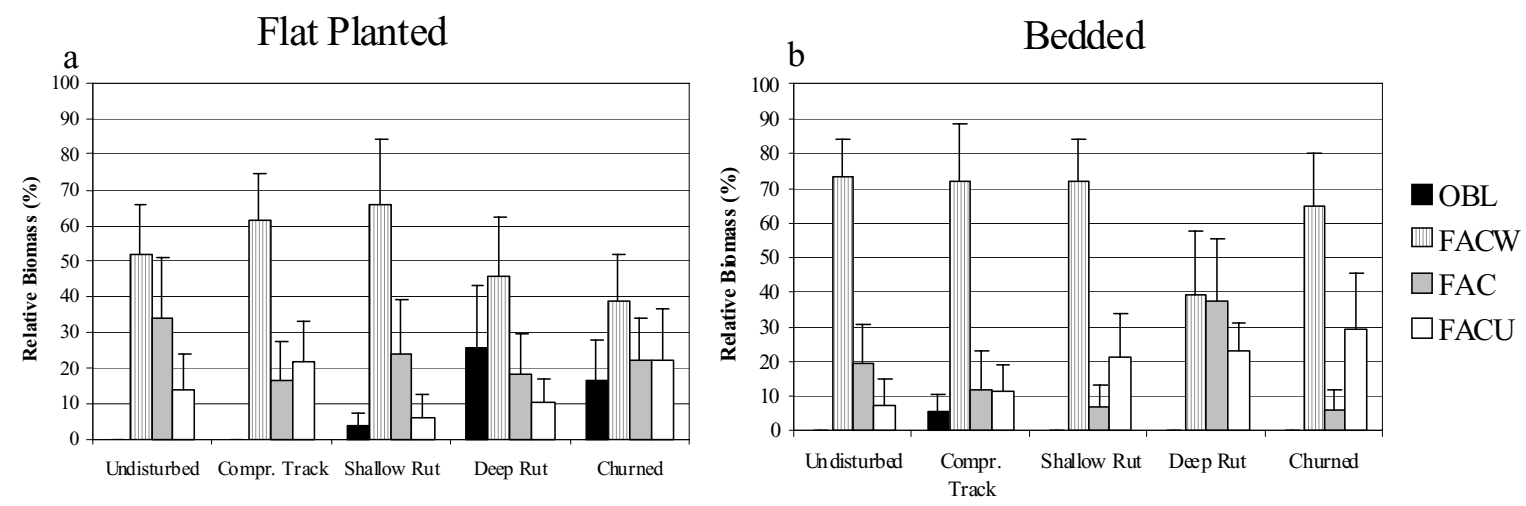

Figure 13. Effects of soil disturbance and site preparation on wetland classification groups for dominant species. 


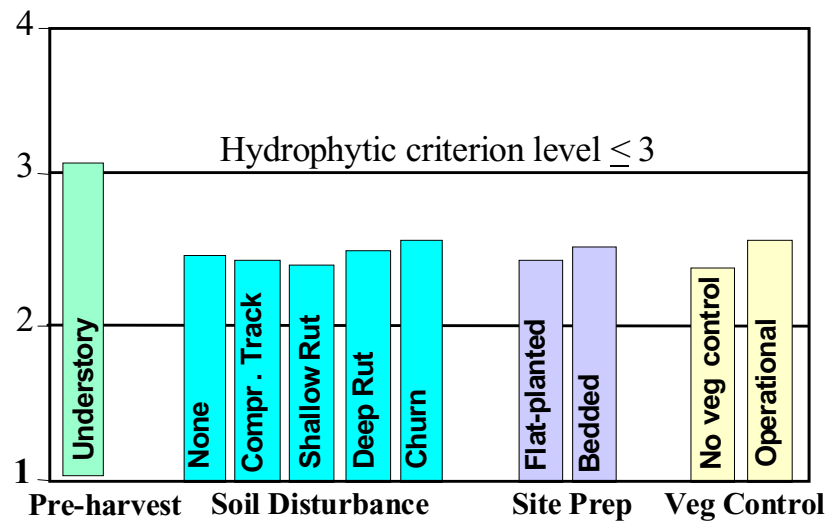

Figure 14. Changes in prevalence index of hydrophytic vegetation.

In addition, we investigated the rates of nitrogen mineralization and sequestration by herbaceous vegetation as affected by weed control that is a common site preparation technique in the southeastern coastal plain. The study shows that on fully vegetated areas, $74 \%$ of the nitrogen mineralized was sequestered, compared to $59 \%$ on the operational and $13 \%$ on total vegetation control treatments, indicating that non-crop vegetation may have played an important role in surface water quality during the post harvest and early stand establishment periods. 


\section{MANAGEMENT IMPLICATIONS}

\section{Wood Production, Carbon Sequestration and Conservation}

- Wetland pine plantations are highly productive and are able to capture over 100 tons per hectare in their biomass for a rotation length of 20 years. This productivity is mainly a function of high soil quality and site hydrology.

Implication: Maintaining and managing site hydrologic conditions is the most important strategy that should be considered in management practices in wetland pine forests.

- Over $35 \%$ of the total biomass carbon is stored in the pine crowns and roots. This amount of biomass can be incorporated into soils for both maintaining soil productivity and conserving carbon.

Implication: It is predictable, at both operational and regional scales, how much carbon will be incorporated into soils at the end of a rotation.

\section{Harvesting Disturbance and Trafficability}

- Trafficability requires high soil strength which is controlled by soil water content. Water perches on the nearly-impermeable clayey horizon. Soil water content is often above the liquid limit, allowing rutting down to the Bt horizon.

Implication: This could be avoided by monitoring critical water contents of the surface and subsurface soil horizons. These critical limits need to be determined for sites commonly logged when wet.

- Nonetheless, tractors can travel on the surface of the Bt most of the year because it does not reach its liquid limit until the permanent water table floods the Bt horizon.

Implication: When this occurs, deep rutting is inevitable regardless of machinery configuration; shovel logging becomes the only option when the permanent water table approaches surface.

\section{Hydrologic Responses to Harvesting and Site Preparation}

- Wet-weather harvesting has little effect on the overall site hydroperiod, yet individual microsites that were significantly disturbed have altered hydroperiods even after two years. Implication: Disturbed microsites with altered hydroperiods may have lower levels of biological productivity over the long term. 
- The hydroperiod of dry-weather harvesting treatments with no site preparation recovers more rapidly than wet-weather harvesting treatments with no site preparation.

Implication: Dry-weather harvesting is especially important on those sites that have a low likelihood of being bedded (NIPFL and public lands).

\section{Soil Quality and Productivity Responses to Harvesting and Site Preparation}

- The Soil Quality Index model explained about 70\% of the variation in above-ground biomass production of two-year-old loblolly pine.

Implication: SQI is a good method for assessing management effects on soil productivity.

- Soil disturbance had no influence on two-year-old loblolly pine productivity flat-planted at a commercial spacing.

Implication: No conclusion should be drawn from this because seedlings were planted on selected microsites and have not sufficiently exploited the disturbed rooting volume. The effect of disturbance will be fully tested after stand closure.

- Bedding successfully mitigated soil productivity of compressed and shallow-rutted sites. Bedding did not fully mitigate deep-rutted sites.

Implication: Wet-weather harvesting influences the quality of site preparation. Rutting is more damaging than churning. BMP assessments should take the ameliorative effects of site preparation into account.

\section{Vegetation Responses and the Role of Vegetation in Soil Recovery}

- Soil disturbance and bedding reduced the growth of woody plant species. Soil rutting and churning created anaerobic microsites that favored the growth of hydrophytic vegetation. Implication: Soil disturbance impedes drainage which enhance wet site indicators. This may or may not have legal implications depending on the degree of wetness.

- Non-crop vegetation appears to play a minor role in the recovery of disturbed soils; however, it may be important for regulating nitrogen supply over time.

Implication: Weed control will have minimal effect on the soil recovery process. On sites subject to nitrogen leaching, weed control could have a negative effect on water quality. 


\section{Wetland Criteria}

- Harvesting and site preparation treatments did not permanently change the prevalence indices of the vegetation towards the drier end of the spectrum.

- Wet-weather harvesting disturbance decreased the depth of soil redoximorphic features.

Implication: Wet-weather harvesting may temporally change border line wetlands into jurisdictional wetlands.

Implication: The current delineation procedures do not adequately capture the temporal and spatial variability of these borderline wetlands.

\section{Regional Silvicultural Implications}

- Harvesting disturbances are site and soil specific and will vary across soil, water, and vegetation gradients.

- Some wetlands may be more resistant and resilient than uplands with regard to harvesting disturbance due to high fertility and good water relations.

- Site disturbance does not necessarily equate to site damage (just because it looks bad, does not mean that it is bad, and the converse).

- Site preparation can mitigate some of the disturbance effects of wet-weather harvesting. 


\section{OTHER RELEVANT PROGRESS}

A database management system was developed for the efficient and accessible use by all research collaborators. All data from field and laboratory measurements were transferred into our data management system. Every effort was made to achieve data quality objectives in terms of precision, accuracy, and completeness of each data set. The data transferred into the data management system were reviewed for high or low (outliers) and any pattern indicating either data entry error or equipment malfunction, e.g, 1) rapid excursion, such as caused by electronic interference; 2) Repetitious values, such as those caused by equipment malfunction; or 3) completeness, at least $95 \%$ of the data available from the sampling system in use. The master data set is well maintained and accessible electronically by all cooperators who request the access password.

Over the past three years, we have achieved all research tasks planned for this project period. Our research team members have contributed more than 20 presentations at regional, national and international scientific meetings and more than 20 scientific articles and technical reports (see below). We will continue to work on data analyses and publish papers aimed for international journals.

An Internet web page introducing our research and results was constructed and disseminated for a broad public audience (http://soils.fw.vt.edu/westvaco/). Especially during the past three years, our project caught increasing attention from both national and international scientific communities. Our project has been received as part of the USDA Forest Service Long-Term Soil Productivity Network, which strengthens our position in exchanging research information and cooperating with researchers across the country.

The project has produced one Master's and two Ph.D. graduate students during the past three years. 


\section{PROJECT-RELATED PUBLICATIONS}

\section{Research Articles}

1) Aust, W.M., J.A. Burger, E.A. Carter, D.P. Preston, S.C. Patterson. 1998. Visuallydetermined soil disturbance classes used as indices of forest harvesting disturbance. South. J. Appl. For. 22(4): 245-250.

2) Burger, J.A. 1997. Conceptual framework for monitoring the impacts of intensive forest management on sustainable forestry. In: P. Hakkila, M. Heino, and E. Puranen (eds.), Forest Management for Bioenergy, 147-156. The Finnish Forest Research Institute. Research Papers 640.

3) Burger, J.A., and D.L Kelting. 1999. Soil quality monitoring for assessing sustainable forest management. In Adams, M.B., Ramakrishna, K. Davidson, E. (eds): Criteria and Indicators for sustainable forest Management. Soil Sci. Soc. Amer. Spec. Pub. 53: 17-52.

4) Burger, J.A., and D.L. Kelting. 1999. Using soil quality indicators to assess forest stand management. For. Ecol. Manage. (122): 155-166.

5) Burger, M.A., 1994. A wetland trafficability hazard index based on soil physical properties and site hydrology evaluations. M.S. Thesis, Virginia Polytechnic Institute and State University, Blacksburg, Virginia, USA, 138 pp.

6) Carter, E.A., W.M. Aust, J.A. Burger, and S.C. Patterson. 1998. Soil strength, volumetric content, and soil roughness characteristics of a bedded wet pine flat. In Proc.: Ninth Biennial Southern Silvicultural Research Conference. Clemson, South Carolina, February 25-27, 1997, 401-405.

7) Kelting, D.L., J.A. Burger, S.C. Patterson, W.M. Aust, M. Miwa, and C.C. Trettin. 1999. Soil quality assessment in domesticated forests -A southern pine example. For. Ecol. Manage. (122): 167-185.

8) Kelting, D.L., J.A. Burger, and S.C. Patterson. 2000. Early loblolly pine growth response to changes in the soil environment. New Zealand J. of For. Sci., Vol. 30 (1/2): 206-224.

9) Kelting, D.L., J.A. Burger, S.C. Patterson. Timber harvesting and site preparation effects on soil quality. Soil Sci. Soc. Amer. J. (in review).

10) Kelting, D.L., J.A. Burger, S.C. Patterson. Early loblolly pine growth response to changes in the soil environment. Soil Sci. Soc. Amer. J. (in review). 
11) Kelting, D.L., J.A. Burger, S.C. Patterson. Timber harvesting and site preparation effects on the soil nutritional environment. Soil Sci. Soc. Amer. J. (in review).

12) Kelting, D.L., J.A. Burger, S.C. Patterson. Forest harvesting and site preparation effects on the soil physical environment. Soil Sci. Soc. Amer. J. (in review).

13) Lister, T.W., J.A. Burger, and S.C. Patterson. Role of vegetation in mitigating soil quality in a two-year-old loblolly pine plantation. Soil Sci. Soc. Amer. J. (in review).

14) Lister, T.W., J.A. Burger, and S.C. Patterson. Silvicultural effects on soil nitrogen in a two-year old loblolly pine plantation. Soil Sci. Soc. Amer. J. (in review).

15) Lister, T.W., J.A. Burger, S.C. Patterson, and W.M. Aust. Silvicultural effects on noncrop vegetation in a two-year-old loblolly pine plantation on a wet forest site. Journal of the Society of Wetland Scientists (in review).

16) Miwa, M., W.M. Aust, J.A. Burger, and S.C. Patterson. 1998. Characterization of disturbed forest soils in the lower coastal plain of South Carolina. In Proc.: Ninth Biennial Southern Silvicultural Research Conference. Clemson, South Carolina, February 25-27, 1997, 379- 385.

17) Miwa, M., W.M. Aust, J.A. Burger, and E.A. Carter. Wet-weather harvesting disturbances and subsequent site preparation: A review of research results for pine plantations on the southeastern coastal plain. For. Ecol. Manage. (In review).

18) Xu, Y.-J., W.M. Aust, J.A. Burger, and S.C. Patterson, and M. Miwa. 1999. Recovery of hydroperiod after timber harvesting in a forested wetland. In Proc. Tenth Bienn. South. Silvic. Res. Conf., USDA For. Serv. Gen. Tech. SRS-30: 282-287.

19) $\mathrm{Xu}$, Y.-J., J.A. Burger, W.M. Aust, and S.C. Patterson. 2000. Responses of surface hydrology and early loblolly pine growth to soil disturbance and site preparation in a lower coastal plain wetland. New Zealand J. of For. Sci., Vol. 30 (1/2): 250-265.

20) Xu, Y.-J., J.A. Burger, W.M. Aust, S.S. Patterson, M. Miwa, and D.P. Preston. Surface water table dynamics from timber harvesting through stand establishment in Atlantic coastal wetlands. Soil \& Tillage Research. (In review).

21) Xu, Y.-J., J.A. Burger, W. M. Aust, and S.C. Patterson. Water table fluctuations on bed and inter-bed in newly established pine forests - Implications for bedding practices on coastal lowlands. Journal of The American Water Resources Association. (In review).

22) Xu, Y.-J., J.A. Burger, W.M. Aust, and S.C. Patterson. Biomass and nutrient pools of three wetland pine forests. Biomass \& Bioenergy. (In review).

23) Xu, Y.-J., J.A. Burger, D.L. Kelting, S.C. Patterson, and W.M. Aust. Changes in carbon 
storage from harvest through stand establishment of loblolly pine in an Atlantic coastal wetland. Forest Ecology and Management. (In review)

\section{Theses and Dissertations}

24) Burger, M.A. 1994. A wetland trafficability hazard index based on soil physical properties and site hydrology evaluations. M.S. Thesis, Virginia Polytechnic Institute and State University, Blacksburg, Virginia, $138 \mathrm{pp}$.

25) Kelting, D.L. 1999. Timber harvesting and site preparation effects on soil quality. Ph.D. Diss. Virginia Polytechnic Institute and State University, Blacksburg, Virginia.

26) Lister, T. W. 1999. Vegetation dynamics and effects on soil processes in a two-year-old loblolly pine plantation. M.S. Thesis, Virginia Polytechnic Institute and State University, Blacksburg, Virginia, 104 pp.

27) Miwa, M. 1999. Physical and hydrological responses of an intensively managed loblolly pine plantation to forest harvesting and site preparation. Ph.D. Diss., Virginia Polytechnic Institute and State University.

28) Preston, D.P., 1996. Harvesting effects on the hydrology of wet pine flats. M.S. Thesis, Virginia Polytechnic Institute and State University, Blacksburg, Virginia, 126 pp.

\section{Presentation Abstracts}

29) Burger, J.A., W.M. Aust, S.C. Patterson, D.L. Kelting, T. Lister, M. Miwa, and Y.-J. Xu. 1998. Monitoring Soil Productivity in a Southern Pine Plantation. Annual Meeting of the Soil Science Scoiety of America, Baltimore, MD, Oct. 18-22, 1998. (National group of scientists)

30) Burger, J.A., M. C. Cerchiaro Y.-J. Xu, S. C. Patterson and W. M. Aust. 1999. Pine Productivity and Soil Quality Response to Harvesting and Site Preparation. International Workshop of International Energy Agency (IEA) Bioenergy Task 18: "Integrating Productivity of Energy in Sustainable Forestry: Guiding Principles and Best Management Practices", September 19-25 1999, Charleston, South Carolina, USA. (International group of scientists)

31) Burger, J.A. Management of soil productivity on wet soils in the Southeastern United States. 2000. Conference on Long-Term Productivity of Forest Soils, Alexandria, Louisiana, October 17 - 19, 2000. (National group of scientists)

32) Eisenbies, M.H., James A. Burger, Yi-Jun Xu, and Steven C. Patterson. 2000. 
Management of Organic Matter or Poorly Drained Alfisols for Pine Production in the Southeast. Annual Meeting of the Soil Science Society of America, Minneapolis, Minnesota, November 5 - 9, 2000. (National group of scientists)

33) Kelting, D.L. and J.A. Burger. 1997. Using soil-based indicators for assessing sustainable forest management: A southern pine example. International Energy Agency Task Force on Sustainable Forest Management, Peebles, Scotland, Sept. 21-25, 1997. (International group of scientists)

34) Kelting, D.L., J.A. Burger, S.C. Patterson, and W.M. Aust. 1998. Improving Forest Management Practices by Monitoring Soil Quality. North American Forest Soils Conference, Lake Tahoe, CA, Aug. , 1998. (National group of scientists)

35) Kelting, D.L., J.A. Burger, S.C. Patterson, W.M. Aust, M. Miwa, and Y.-J. Xu. 1998. Early Loblolly Pine Growth Response to Changes in the Soil Environment. Annual Meeting of the Soil Science Scoiety of America, Baltimore, MD, Oct. 18-22, 1998. (National group of scientists)

36) Kelting, D.L., J.A. Burger, and S.C. Patterson. 1999. Early loblolly pine growth response to changes in the soil environment. Bioenergy Task 18 Workshop of International Energy Agency (IEA), September 19-25, 1999, Charleston, South Carolina. (International group of scientists)

37) Kelting, D.L., J.A. Burger, and S.C. Patterson. 1999. Soil disturbance and site preparation Effects on nitrogen supply in young loblolly pine plantations. American Society of Agronomy (ASA)/Crop Science Society of America (CSSA)/Soil Science Society of America Annual Meetings, October 31-November 4, 1999, Salt Lake City, Utah. (National group of scientists)

38) Lister, T.W., J.A Burger, S.C. Patterson, W.M. Aust, and R.H. Jones. 1998. Vegetation Dynamics and Effects on Soil Processes in a Two Year Old Loblolly Pine Plantation. Annual Meeting of the Soil Science Scoiety of America, Baltimore, MD, Oct. 18-22, 1998. (National group of scientists)

39) Miwa, M., W.M. Aust, J.A. Burger, and S.C. Patterson. 1995. Spatial characterization of harvesting effects on forest soil and groundwater hydrology in southeast coastal plain flat-woods sites. Annual Meeting of the Soil Science Society of America, St. Louis, MO, Oct 29-Nov. 3, 1995. (National group of scientists)

40) Miwa, M., W.M. Aust, J.A. Burger, and S.C. Patterson. 1997. Characterization of disturbed forest soils in the lower coastal plain of South Carolina. Ninth Biennial Southern Silvicultural Research Conference, Clemson, SC, Feb. 25-27, 1997. (Regional group of scientists, foresters, and policymakers)

41) Miwa, M., W.M. Aust, J.A. Burger, S.C. Patterson, and Y.-J. Xu. 1998. Comparison of 
Disturbed and Ameliorated Soils Two Years After Forest Harvesting. Annual Meeting of the Soil Science Scoiety of America, Baltimore, MD, Oct. 18-22, 1998. (National group of scientists)

42) Miwa, M., W.M. Aust, J.A. Burger, Y.J. Xu. 1999. Harvesting and site preparation effects on the hydrology of wet flat pine plantations. Tenth Biennial Southern Silvicultural Research Conference, February 16-18, 1999, Shreveport, Louisiana. (Regional group of scientists, foresters, and policymakers)

43) Miwa, M., W.M. Aust, J.A. Burger, Y.-J. Xu, and S.C. Patterson. 1999. Characterization of site hydrology of a southeastern lower coastal plain wet pine flat. American Society of Agronomy (ASA)/Crop Science Society of America (CSSA)/Soil Science Society of America Annual Meetings, October 31-November 4 1999, Salt Lake City, Utah. (National group of scientists)

44) Xu, Y.-J., M. Miwa, W.M. Aust, J.A. Burger, and S.C. Patterson. 1998. Long-term water table dynamics of a wetland pine forest in the southeastern US coastal plain. Annual Meeting of the Soil Science Society of America, Baltimore, MD, Oct. 18-22, 1998. (National group of scientists)

45) Xu, Y.-J., J. Burger, W.M. Aust, S.C. Patterson, D. Kelting, M. Miwa, and T. Lister. 1998. Forest productivity under altered soil hydraulic and physical conditions in wetlands. Annual Meeting of the Soil Science Scoiety of America, Baltimore, MD, Oct. 18-22, 1998. (National group of scientists)

46) Xu, Y.-J., W.M. Aust, J.A. Burger, and S.C. Patterson, and M. Miwa. 1999. Recovery of hydroperiod after timber harvesting in forested wetlands. Tenth Bienn. South. Silvic. Res. Conf., Louisiana, February 1999. (Regional group of scientists, foresters, and policymakers)

47) Xu, Y.-J., J.A. Burger, W.M. Aust, and S.C. Patterson. 1999. Assessing timber harvesting impacts on hydrologic functions and site productivity in a managed wetland forest in the southeastern United States. Bioenergy Task 18 Workshop of International Energy Agency (IEA), Charleston, South Carolina, USA, Sept 16-21, 1999. (International group of scientists)

48) Xu, Y.-J., J.A. Burger, S.C. Patterson, and M.C. Cerchiaro. 1999. The importance of silvicultural practices on carbon storage and dynamics in managed forests in the southeastern United States. Bioenergy Task 18 Workshop of International Energy Agency (IEA), Charleston, South Carolina, USA, Sept 16-21, 1999. (International group of scientists)

49) Xu, Y.-J., J.A. Burger, D.L. Kelting, S.C. Patterson, and W.M. Aust. 1999. Carbon storage dynamics from harvesting through stand establishment in a wetland pine plantation. ASA/CSSA/SSSA Meetings, Salt Lake City, Utah, USA, Oct 31-Nov 51999. 
(National group of scientists)

50) Xu, Y.-J. and S.P. Prisley. 2000. Linking STATSGO and FIA data for spatial and temporal analyses of carbon storage in forested land areas. The 3rd Southern Forestry GIS conference, Athen, Georgia, USA, October 2000. (Regional group of scientists and forest managers)

51) Xu, Y.-J., J. A. Burger, S.C. Patterson, and M.H. Eisenbies. 2000. End of a rotation stand biomass and carbon redistribution in managed wetland pine forests. Conference on LongTerm Productivity of Forest Soils, Alexandria, Louisiana, October 17 - 19, 2000. (National group of scientists)

52) Xu, Y.J., J.A. Burger, W.M Aust, and S.C. Patterson. 2000. Spatiotemporal distributions of surface water table in a forested wetland. Annual ASA/CSSA/SSSA Meetings, Minneapolis, Minnesota, November 5-9, 2000. (National group of scientists)

\section{Project Progress Reports}

\section{Quarterly Progress Reports:}

- Reporting period July 1 to August 31, 2000

- Reporting period April 1 to June 30, 2000

- Reporting period January 1 to March 31, 2000

- Reporting period October 1 to December 31, 1999

- Reporting period July 1 to September 31, 1999

- Reporting period April 1 to June 30, 1999

- Reporting period July 1 to September 30, 1998

- Reporting period April 1 to June 30, 1998

- Reporting period January 1 to March 31, 2000

- Reporting period October 1 to December 31, 1997

- Reporting period July 1 to September 30, 1997

\section{Annual Project Reports:}

- Project Progress Report 1997

- Project Progress Report to the US Department of Energy. January 1999

- Project Progress Report for Project Review Meeting in Charleston, SC, February 1999 


\section{LITERATURE CITED}

Allen, H.L., Campbell, R.G., 1988. Wet site pine management in the southeastern United States. In: Hook, D.D. (Ed.), The ecology and management of wetlands: Volume 2. Management, use, and value of wetlands, Timber Press, Portland, OR, pp. 173-184.

Aust, W.M., and Lea, R., 1992. Comparative effects of aerial and ground logging on soil properties in a tupelo-cypress wetland. For. Ecol. Manage., 50, 57-73.

Aust, W.M., Reisinger, T.W., Burger, J.A., Stokes, B.J., 1993. Soil physical and hydrologic changes associated with logging a wet pine flat with wide-tired skidders. South. J. Appl. For. 17, 22-25.

Aust, W.M., Burger, J.A., Carter, E.A., Preston, D.P., Patterson, S.C., 1998. Visually determined soil disturbance classes used as indices of forest harvesting disturbance. South. $J$. Appl. For. 22, 245-250.

Barnes, K.K., Carleton, W.M., Taylor, H.M., Throckmorton, R.I., VanDen Berg, G.E., (Eds.), 1971. Compaction of agricultural soils. Am. Soc. Agric. Eng., St. Joseph, MI, U.S.A., 471 pp.

Bodman, G.B., Rubin, J., 1948. Soil puddling. Soil Sci. Soc. Am. Proc., 13, 27-36.

Bohn, H.L., B.L. McNeal, and G.A. O'Connor. 1985. Soil Chemistry. Second Edition. John Wiley and Sons, New York.

Brennan, E.W., and W.L. Lindsay. 1998. Reduction and oxidation effect on the solubility and transformation of iron oxides. Soil Sci. Soc. Am. J. 62:930-937.

Chancellor, W.J. 1976. Compaction of soil by agricultural equipment. Univ. California, Davis, CA, U.S.A., Bull. 1881, 53pp.

Cain, M.D., 1978. Planted loblolly and slash pine response to bedding and flat disking on a poorly drained site. USDA For. Serv. Res. Note, SO-237, 6 pp.

Conde, L. F., Swindel, B.F., Smith, J.E., 1983a. Plant species cover, frequency, and biomass: Early responses to clearcutting, chopping, and bedding in Pinus elliottii flatwoods. For. Ecol. Manage. 6, 307-317.

Cowardin, L.M., Carter, V., Golet, F.C., Laroe, E.T., 1979. Classification of wetlands and deepwater habitats of the United States. USDI Fish \& Wildlife Serv., Washington, DC. FWS/OBS-79/31, 131 pp.

Dulohery, C.J., L.A. Morris, and R. Lowrance. 1996. Assessing forest soil disturbance 
through biogenic gas fluxes. Soil Sci. Soc. Am. J. 60:291-298.

Froehlich, H.A., Azevedo, J., Cafferata, P., Lysne, D., 1980. Predicting soil compaction on forested land. USDA Forest Service, Equip. Dev. Centre, Missoula, MT, U.S.A., 120 pp.

Fröhlich, O.K. 1934. Druckverteilung im Baugrund. (Pressure distribution in soil foundation). Springer, Berling, Germany, 178 pp. (In German).

Gent, J.A., Jr., Ballard, R., Hassan, A.E., 1983. The impact of harvesting and site preparation on the physical properties of Lower Coastal Plain forest soils. Soil Sci. Soc. Am. J. 47, 595-598.

Gradwell, M.W., 1966. Soil moisture deficiencies in puddled pastures. N. Z. J. Agric. Res. 9, 127-136.

Greacen, E.L, Sands, R., 1980. Compaction of forest soils. A Review. Aust. J. Res., 18, 163189.

Haywood, J.D., 1983. Response of planted pines to site preparation on Beauregard-Caddo soil. In: Jones, E.P., Jr. (Ed.), Proc. 2nd Bienn. South. Silvic. Res. Conf., USDA For. Serv. Gen. Tech. Rep. SE-24, pp. 14-17.

Jastrow, J.D. and Miller, R.M. 1991. Methods for assessing the effects of the biota on soil structure. Agric. Ecosyst. Environ. 34:279-303.

Kögler, A., 1933. Baugrundprüfung im Bohrloch. (Soil foundation testing). Der Bauingenieur 8, 266-270. (In German).

Koolen, A.J., Kuipers, H., 1983. Agricultural soil mechanics. Springer, Berlin, Germany, 241 pp.

McBride, M.B. 1994. Environmental Chemistry of Soils. Oxford University Press, New York.

McKee, W.H. 1970. Chemical properties of a forest soil affected by fertilization and submergence. Soil Sci. Soc. Am. Proc. 34:690-693.

McKee, W.H., and M.R. McKevlin. 1993. Geochemical processes and nutrient uptake by plants in hydric soils. Environ. Toxic. Chem. 12:2197-2207.

Paul, E.A., and F.E. Clark. 1989. Soil Microbiology and Biochemistry. Academic Press, Inc., New York.

Ponnamperuma, F.N. 1984. Effects of flooding on soils. p. 10-42. In Kozlowski (ed) Flooding and Plant Growth. Academic Press, Inc., New York. 
Powers, R.F. 1980. Mineralizable soil nitrogen as an index of nitrogen availability to forest trees. Soil Sci. Soc. Am. J. 44:1314-1320.

SAS Institute Inc., 1988. SAS/STAT User's Guide, Release 6.03 Edition, SAS Institute Inc., $\mathrm{NC}, 1028 \mathrm{pp}$

Shepard, J.P., Brady, S.J., Cost, N.D., Storrs, C.G., 1998. Classification and inventory. In: Messina, M.G., Conner, W.H. (Eds.), Southern Forested Wetlands Ecology and Management. Lewis Publishers, New York, pp. 3-28.

Soane, B.D., Blackwell, P.S., Dickson, J.W., Painter, D.J., 1981a. Compaction by agricultural vehicles: A review. I. Soil and wheel characteristics. Soil \& Tillage Res., 1, 207-237.

Soane, B.D., Blackwell, P.S., Dickson, J.W., Painter, D.J., 1981b. Compaction by agricultural vehicles: A review. II. Compaction under tyres and other running gear. Soil \& Tillage Res., 1, 373-400.

Soane, B.D., Dickson, J.W., Campbell, D.J., 1982. Compaction by agricultural vehicles: A review. III. Incidence and control of compaction in crop production. Soil \& Tillage Res., 2, 3-36.

Soane, B.D., van Ouwerkerk, C. (Eds.), 1994. Soil compaction in crop production. Developments in Agricultural Engineering 11. Elsevier. 662 pp.

Söhne, W., 1951. Das mechanische Verhalten des Ackerbodens bei Belastung unter rollenden Rädern sowie bei der Bodenbearbeitung. (Mechanical behaviors of agricultural soils under stresses of rolling wheels and during tillage). Grundl. Landtech., 9. Konstrukteur Heft 1, 87-94 (in German).

Söhne, W., 1952. Die Kraftbertragun zwischen Sclepperreifen und Ackerboden. (The transmission of forces between tractor tires and agricultural soils). Grundl. Landtech., 3, 75-87 (in German).

Söhne, W., 1953. Druckverteilung im Boden und Bodenverformung unter Schlepperreifen. (Pressure distribution in soils and soil deformation under tractor tires). Grundl. Landtech., 5, 49-63 (in German).

Söhne, W., 1958. Fundamentals of pressure distribution and soil compaction under tractor tires. Agric. Eng., 39, 279-281, 290.

Stone, E.L. (Ed.), 1984. Forest soils and treatment impacts. Proc. $6^{\text {th }}$ Conf. North American Forest Soils, June 1983, Soc. Am. Foresters/Dept. Forestry, Wildlife and Fisheries, Univ. Tennessee, Knoxville, TN, U.S.A.

Stout, I.J., Marion, W.R., 1993. Pine flatwoods and Xeric pine forests of the southern (lower) 
coastal plain. In: Martin, W.H., Boyce, S.G., Echternacht, A.C. (Eds.), Biodiversity of the Southeastern United State: Lowland terrestrial communities. John Wiley \& Sons. New York, pp.

Stransky, J.J., Huntley, J.C., Risner, W. J., 1986. Net community production dynamics in the herb-shrub stratum of a loblolly pine-hardwood forest: Effects of clearcutting and site preparation. USDA Forest Service General Technical Report -SO 61, 1-11.

Swindel, R.F., Smith, J.E., Outcalt, K.W., 1989. Long term response of competing vegetation to mechanical site preparation in pine plantations. General Technical Report-SO, USDA Forest Service SE Experimental Station, New Orleans 74, 123-127.

Tiarks, A.E., 1983. Effect of site preparation and fertilization on slash pine growing on a good site. In: Jones, E.P., Jr. (Ed.), Proc. 2nd Bienn. South. Silvic. Res. Conf., USDA For. Serv. Gen. Tech. Rep. SE-24, pp. 34-39.

Wilhite, L.P., Jones, E.P., Jr., 1981. Bedding effects on maturing slash pine stands. South. J. Appl. For. 5, 24-27.

Worrell, R., Hampson, A., 1997. The influence of some forest operations on the sustainable management of forest soils - A review. Forestry 70 (1), 61-85. 